\title{
Infliction of proteotoxic stresses by impairment of the unfolded protein response or proteasomal inhibition as a therapeutic strategy for mast cell leukemia
}

\author{
Thomas Wilhelm ${ }^{1}$, Fabian Bick ${ }^{1}$, Kerstin Peters ${ }^{1}$, Vrinda Mohta ${ }^{1}$, Boaz Tirosh ${ }^{2}$, John \\ B. Patterson ${ }^{3}$, Behzad Kharabi-Masouleh ${ }^{4}$ and Michael Huber ${ }^{1}$ \\ ${ }^{1}$ Institute of Biochemistry and Molecular Immunology, Medical Faculty, RWTH Aachen University, Aachen, Germany \\ 2 The Institute of Drug Research, The Hebrew University of Jerusalem, Jerusalem, Israel \\ ${ }^{3}$ Fosun Orinove, Inc., Newbury Park, CA, USA \\ ${ }^{4}$ Department of Hematology, Oncology, Hemostaseology and Stem Cell Transplantation, Medical Faculty, RWTH Aachen \\ University, Aachen, Germany
}

Correspondence to: Michael Huber, email: mhuber@ukaachen.de

Keywords: IREla; proteasome; proteostasis; stress kinase; XBP 1

Received: October 07, $2017 \quad$ Accepted: December 03, $2017 \quad$ Published: December 17, 2017

Copyright: Wilhelm et al. This is an open-access article distributed under the terms of the Creative Commons Attribution License 3.0 (CC BY 3.0), which permits unrestricted use, distribution, and reproduction in any medium, provided the original author and source are credited.

\section{ABSTRACT}

The intensity and duration of endoplasmic reticulum (ER) stress converts the unfolded protein response (UPR) from an adaptive into a terminal response. The first regulates homeostasis, the latter triggers apoptosis. Cells that rapidly proliferate and possess developed secretory capabilities, such as leukemia cells, depend on an efficiently operating UPR to maintain proteostasis. Activation of terminal UPR by either blockade of adaptive UPR or exaggeration of ER stress has been explored as a novel approach in cancer therapy. For mast cell leukemia (MCL) the efficacy of both approaches, by utilizing the KIT ${ }^{\mathrm{V} 5606,0816 \mathrm{~V}}$-positive MCL cell line HMC-1.2, was investigated. We show that HMC-1.2 cells display a tonic activation of the IRE1a arm of the UPR, which constitutively generates spliced XBP1. Inhibition of IRE1a by different types of inhibitors (MKC-8866, STF-083010, and KIRA6) suppressed proliferation at concentrations needed for blockade of IRE1a-mediated XBP1 splicing. At higher concentrations, these inhibitors triggered an apoptotic response. Blocking the proteasome by bortezomib, which confers an exaggerated UPR, resulted in a marked cytotoxic response. Bortezomib treatment also caused activation of the kinase JNK, which played a pro-proliferative and anti-apoptotic role. Hence, the combination of bortezomib with a JNK inhibitor synergized to induce cell death. In summary, the UPR can be addressed as an effective therapeutic target against $\mathrm{KIT}^{\mathrm{D} 816 \mathrm{~V}}$-positive MCL.

\section{INTRODUCTION}

For physiological performance, cells depend on a functional proteostasis network enabling proper protein expression, folding, transport and topology, as well as the capability to stringently control and, when necessary, to correct these processes upon stressful perturbations [1]. The endoplasmic reticulum (ER) is the port of entry of proteins into the secretory pathway. Particularly in cells with a pronounced proliferative and/or secretory phenotype, such as cancer cells, extensive protein and membrane production as well as protein folding tasks are required. Hence, cancer cells exhibit vulnerability to the accumulation of misfolded proteins in the ER. An elaborate system comprising sensors, transcription factors and chaperones, called the unfolded protein response (UPR), has been evolutionary established to maintain proteostasis [2, 3]. Three transmembrane sensor proteins located in the ER membrane form the backbone of the UPR - inositol-requiring enzyme $1 \alpha$ (IRE1 $\alpha$ ), doublestranded RNA-activated protein kinase-like ER kinase (PERK), and activating transcription factor 6 (ATF6) - each containing a luminal domain that allows their 
activation by recognition of misfolded proteins $[2,3]$.

IRE $1 \alpha$ contains a serine/threonine kinase and an endoribonuclease domain in its cytoplasmic domain. After activation, the latter splices the mRNA of the transcription factor XBP1, causing a shift in the reading frame and allowing for translation of the "spliced" transcription factor XBP1s, which enters the nucleus and controls the production of a large number of ER chaperones as well as proteins involved in ER-associated protein degradation (ERAD), amongst others $[2,4]$. Moreover, in a process called "regulated IRE1-dependent decay of mRNA (RIDD)" IRE1 $\alpha$ can cleave additional ER-localized mRNAs [5]. Activated PERK phosphorylates and thereby inactivates the translation initiation factor eIF $2 \alpha$, resulting in a global attenuation of protein synthesis. Paradoxically, phosphorylated eIF $2 \alpha$ promotes translation of several proteins, a prominent one being the pro-apoptotic transcription factor ATF4 $[2,6]$. The third sensor, ATF6, upon ER stress, de-oligomerizes and translocates from the ER to the Golgi apparatus, where it is cleaved by membrane-bound proteases in its cytoplasmic domain. Cleavage results in the release of the $\mathrm{N}$-terminal domain, which subsequently enters the nucleus and acts as a transcription factor $[2,7]$.

The context-dependent cooperation of these sensors and the respective transcription factors allow for cellular responses ranging from adaptation to apoptosis [2]. This apoptotic switch has been utilized already for the treatment of the plasma cell malignancy called multiple myeloma (MM), the cells of which exert marked secretory capacity and constitutively depend on the UPR $[8,9]$. To induce UPR-directed apoptosis, the proteasome inhibitor bortezomib (BZ), which has been established as a standard of care for MM patients, was applied to impede degradation of misfolded proteins by the proteasome in the ERAD pathway, thus enhancing the protein load of the ER and tipping the balance of the stress response towards apoptosis. In addition to proteasome inhibitors, the glycosylation inhibitor tunicamycin (TM), the inhibitor of the sarcoplasmic/endoplasmic reticulum $\mathrm{Ca}^{2+}$ dependent ATPase (SERCA), thapsigargin, as well as the reducing agent dithiothreitol (DTT) are frequently used to artificially induce the UPR [10].

Systemic mastocytosis (SM) is a clonal mast cell (MC) disease exhibiting various characteristics from indolent mastocytosis to aggressive mastocytosis and MC leukemia (MCL) [11, 12]. SM features abnormal proliferation and accumulation of MCs in various tissues and organs $[11,12]$. The receptor tyrosine kinase KIT plays a central role in MC biology by promoting development, survival, proliferation, chemotaxis as well as proinflammatory mediator production and release [12, 13]. Mutations in KIT can be found in most cases of SM, with $\mathrm{KIT}^{\mathrm{D} 816 \mathrm{~V}}$ being the most prevalent and detectable in more than $80 \%$ of patients $[11,12]$. Since KIT ${ }^{\mathrm{D} 816 \mathrm{~V}}$ may be found in all variants of SM (from indolent SM to MCL) with comparable prevalence [14], mutations in additional genes might be present causing the differences in disease severity. Indeed, mutations in genes encoding for various signaling proteins, epigenetic regulators, transcription factors, and splicing factors were identified [15-17]. Moreover, a thorough molecular analysis of myeloid progenitor cells in multi-mutated advanced SM revealed KIT ${ }^{\mathrm{D} 16 \mathrm{~V}}$ as a late event [18]. Nevertheless, it is understood that $\mathrm{KIT}^{\mathrm{D} 816 \mathrm{~V}}$ is important in SM regarding $\mathrm{MC}$ proliferation and survival. Inhibition of KIT ${ }^{\mathrm{D} 816 \mathrm{~V}}$ by established tyrosine kinase inhibitors (TKIs), however, faces several problems. KIT ${ }^{\mathrm{D} 816 \mathrm{~V}}$ is resistant to the first generation TKI imatinib and high concentrations of the second generation TKI nilotinib are required for its inhibition $[19,20]$. Two further second generation TKIs, dasatinib and midostaurin, and the third generation TKI ponatinib can suppress $\mathrm{KIT}^{\mathrm{D} 816 \mathrm{~V}}$-driven cellular activities in vitro [21-24], however, the determination of drugprotein interaction profiles as well as phosphoproteome analyses revealed restricted selectivity, offering the possibility of unwanted side effects [25-28]. Nevertheless, recent studies revealed effectiveness of nilotinib and midostaurin in a number of patients with advanced systemic mastocytosis, including highly fatal MCL [29, 30]. However, further kinases except KIT, such as the SRC family kinase LYN, the TEC family kinase BTK, and the mitosis-regulating serine/threonine kinase PLK1, have been demonstrated to be involved in the regulation of proliferation and survival of MCL cell lines as well as patient cells [31,32], which might account for patient- and situation-specific restricted efficacy of the above mentioned TKIs. Hence, further TKI-independent therapies or the use of synergistically acting drug combinations should be developed.

In this study, we have approached the importance of the UPR in MCL and analyzed the efficacy of various UPR inhibitors and pharmacological inducers of ER stress to suppress proliferation and survival of the KIT ${ }^{\mathrm{V} 560 \mathrm{G}, \mathrm{D} 816 \mathrm{~V}}$ positive human MCL cell line HMC-1.2. In addition, we unraveled the potency of a combination of $\mathrm{BZ}$ and the JNK inhibitor JNK-IN-8 to efficiently induce apoptosis in $\mathrm{KIT}^{\mathrm{D} 816 \mathrm{~V}}$-positive MCL cells.

\section{RESULTS}

\section{Inhibition of the IRE1 $1 \alpha$ arm of the UPR suppresses proliferation and survival of HMC1.2 cells}

In a situation-dependent manner, the UPR can result in an adaptive, pro-homeostatic or in a terminal, proapoptotic cellular response. Cells that rapidly proliferate and possess developed secretory functions are particularly dependent on a functional adaptive UPR to cope with the 
synthetic demand of the ER. Thus, we interrogated the $\mathrm{KIT}^{\mathrm{V} 560 \mathrm{G}, \mathrm{D} 816 \mathrm{~V}}$-positive human MCL cell line HMC-1.2 for a constitutively active UPR by determining activation of the UPR sensor IRE1 $\alpha$. Occurrence of spliced $X B P 1$ mRNA $(X B P 1 s)$ was taken as the read-out for IRE1 $\alpha$ activation. First, we applied an $X B P 1$ splicing detection
A

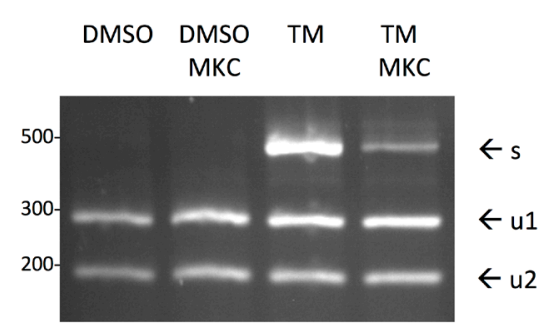

C

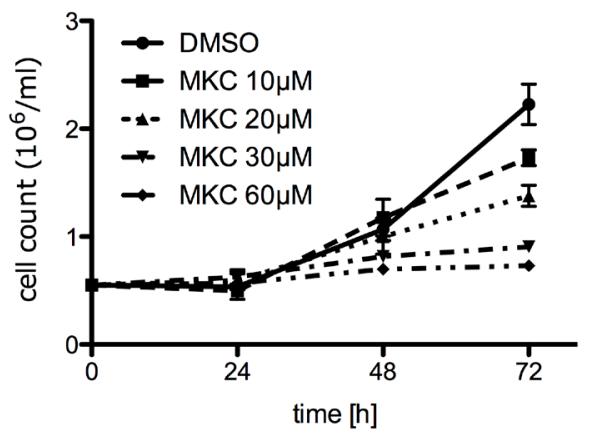

E

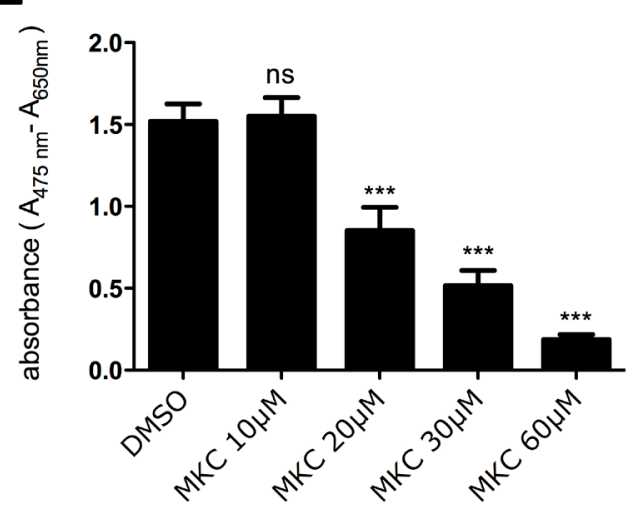

B

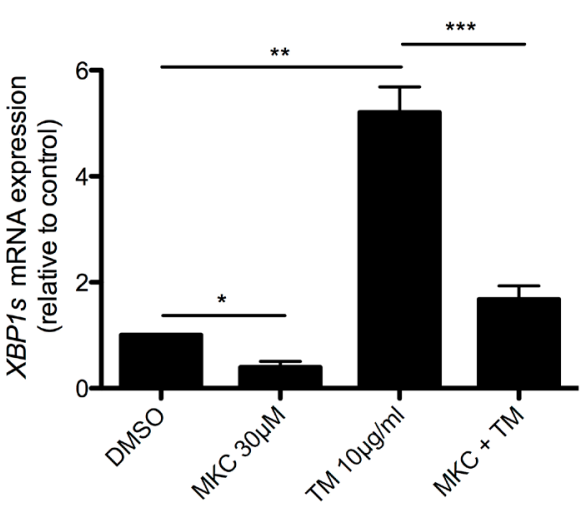

D

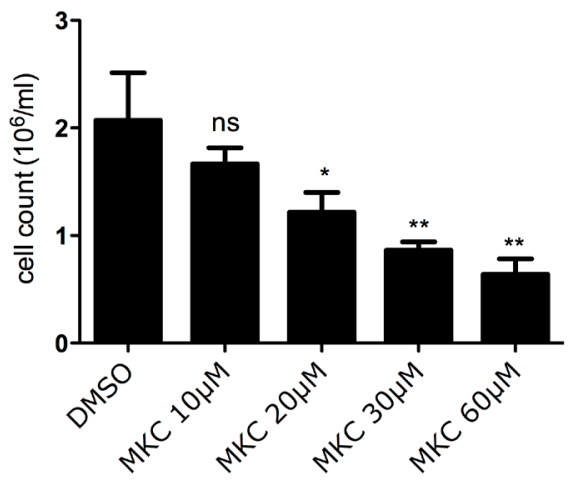

$\mathbf{F}$

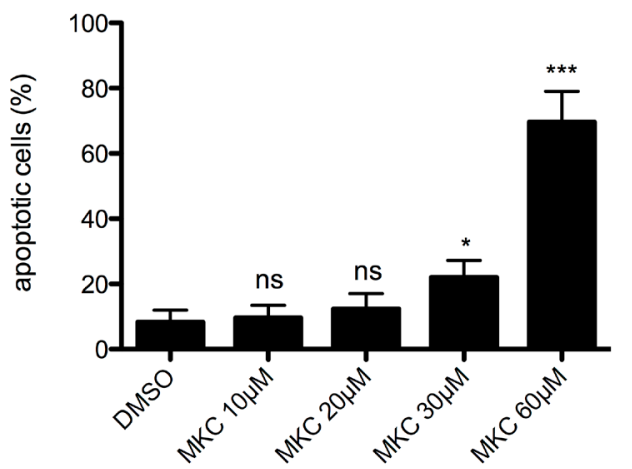

Figure 1: Inhibition of active IRE1 $\alpha$ by MKC-8866 mainly suppresses proliferation of HMC-1.2 cells. A. Expression of spliced XBP1 mRNA was evaluated by an XBP1 splicing detection assay. HMC-1.2 cells were pre-incubated with vehicle (DMSO) or $30 \mu \mathrm{M}$ MKC-8866 (MKC) for $1 \mathrm{~h}$ followed by $6 \mathrm{~h}$ treatment with $10 \mu \mathrm{g} / \mathrm{ml} \mathrm{TM}$. Generated cDNA was used to amplify XBP1 by PCR. XBP1u amplicon digestion by PstI resulted in two fragments ( $u 1, u 2)$. Size of XBP1s amplicon lacking PstI sites was 473bp. B. HMC-1.2 cells were treated for $1 \mathrm{~h}$ with vehicle (DMSO) or $30 \mu \mathrm{M}$ MKC followed by $6 \mathrm{~h}$ treatment with $10 \mu \mathrm{g} / \mathrm{ml} \mathrm{TM}$. XBP1s expression was evaluated by RT-qPCR and normalized to HPRT. ( $\mathrm{n}=3) \mathrm{C}$. Proliferation was measured by Casy cell counter every $24 \mathrm{~h}$ for up to $72 \mathrm{~h}$. HMC-1.2 cells were treated with vehicle (DMSO) or with the indicated concentrations of MKC. Proliferation graphs of a representative experiment are shown. D. Statistical analysis of cell counts after $72 \mathrm{~h}$ of independent experiments as measured in C. $(\mathrm{n}=3)$ E. Metabolic activity was measured by XTT assay after $72 \mathrm{~h}$ treatment with the indicated concentrations of MKC (or vehicle). ( $\mathrm{n}=5$ ) F. Cell viability was measured by FACS analysis of Annexin V/ propidium iodide stained HMC-1.2 cells treated for 72h with vehicle (DMSO) or the indicated concentrations of MKC. $(\mathrm{n}=3)$ Data show mean $\pm \mathrm{SD}$ from $\mathrm{n} \geq 3$ independent experiments. Student's $t$-Test and one-sample $t$-Test were performed to calculate the p-values. ${ }^{*} p<0.05, * * p<0.01, * * * p<0.001$. 
assay involving mRNA amplification by RT-PCR followed by diagnostic restriction digest. As a positive control, cells were treated with TM for $6 \mathrm{~h}$. As expected, TM induced a strong splicing of XBP1 mRNA, which was suppressed by the IRE1 $\alpha$ inhibitor MKC-8866, which targets the endonuclease domain of IRE1 $\alpha$ (Figure $1 \mathrm{~A})$. In single experiments, a faint band of $X B P 1 \mathrm{~s}$ was already detectable in proliferating HMC-1.2 cells (data not shown), suggesting a weak basal activity of IRE1 $\alpha$ in HMC- 1.2 cells. The data obtained with the $X B P 1$ splicing detection assay were corroborated using $X B P 1 s$-specific RT-qPCR (Figure 1B). Owing to the enhanced sensitivity of the RT-qPCR approach, significant reduction of basal $X B P 1 s$ mRNA by MKC-8866 was measurable, indicating once more the basal activation of IRE1 $\alpha$ in proliferating HMC- 1.2 cells. Noteworthy, constitutive activation of an UPR is not a feature of every cell type. Assuming that IRE $1 \alpha$ activity is needed to promote growth of HMC1.2 MCL cells, we next investigated if blocking IRE1 $\alpha$ activity might confer inhibition of proliferation. HMC-1.2 cells were treated with increasing concentrations of $\mathrm{MKC}$ $8866(10-60 \mu \mathrm{M})$ or vehicle control and cell numbers were determined every $24 \mathrm{~h}$ using an analytical cell counter. Indeed, inhibition of IRE1 $\alpha$ resulted in significant suppression of HMC-1.2 proliferation after $72 \mathrm{~h}$ treatment (Figure 1C \& 1D). To verify these data and to combine them with information on metabolic activity, XTT assays were performed. Incubation (72h) with MKC-8866 caused a dose-dependent decline in metabolic activity (Figure 1E). Compared to the sole determination of cell numbers (Figure 1D), a marked diminution of XTT positivity was evident from $30 \mu \mathrm{M}$ to $60 \mu \mathrm{M}$ of MKC-8866, suggesting appearance of an additional quality in the presence of $60 \mu \mathrm{M}$ MKC-8866 (Figure 1E). Therefore, we analyzed induction of cell death in MKC-8866-treated HMC-1.2 cells by staining with AV/PI. Whereas 10 - $30 \mu \mathrm{M}$ MKC8866 induced only little cell death, $60 \mu \mathrm{M}$ MKC-8866 caused up to $60 \%$ of AV/PI-positive cells (Figure 1F; Supplementary Figure 1A), paralleling the decline in XTT positivity at this concentration of the inhibitor (Figure $1 \mathrm{E})$, thus corroborating qualitatively differential effects dependent on inhibitor concentration. Comparable results were obtained analyzing the effects of MKC-8866 on $\mathrm{KIT}^{\mathrm{V} 560 \mathrm{G}}$-positive HMC-1.1 cells (data not shown).

To corroborate the effect of MKC-8866-mediated IRE1 $\alpha$ inhibition, two additional pharmacological inhibitors of IRE1 $\alpha$ were tested: the IRE $1 \alpha$ endonucleasespecific inhibitor STF-083010 [33] and the ATPcompetitive IRE1 $\alpha$ kinase-inhibiting RNase attenuator KIRA6 [34]. Both inhibitors significantly and dosedependently suppressed proliferation determined by cell counting (Figure 2A \& 2B) and metabolic activity of HMC-1.2 cells as measured by XTT assays (Figure $2 \mathrm{C} \& 2 \mathrm{D})$. In line with the data obtained with MKC8866, both STF-083010 and KIRA6 induced cell death at higher concentrations in an escalating manner (STF-
083010: compare 30 and 60/100 $\mu \mathrm{M}$; KIRA6: compare 1 and $3 / 10 \mu \mathrm{M}$ ) (Figure 2E \& 2F; Supplementary Figure $1 \mathrm{~B} \& 1 \mathrm{C})$. This was intriguing all the more since an effective blockade of XBP1 splicing was already obtained using the lower concentrations of both inhibitors (STF083010: $30 \mu \mathrm{M}$; KIRA6: $1 \mu \mathrm{M}$ ) (Supplementary Figure 2). Particularly KIRA6 was a potent inducer of cell death, potentially owing to its dual activity inhibiting both the endonuclease activity as well as the kinase activity of IRE1 $\alpha$. In conclusion, proliferation and survival of the human MCL cell line HMC-1.2 rely on a functional UPR, in particular signaling from the UPR sensor IRE $1 \alpha$, and indicate the potential of IRE $1 \alpha$ inhibitors as pharmacological treatment for patients suffering from MCL.

\section{Constitutive activation of PERK in HMC-1.2 cells does not support proliferation and survival}

Motivated by the finding of basal UPR activity in HMC-1.2 cells, we investigated activation of the second UPR sensor, PERK, in proliferating HMC-1.2 cells. Phosphorylation of the translation initiation factor eIF $2 \alpha$ was taken as a read-out for PERK activity. Phosphospecific immunoblot analysis of eIF2 $\alpha$ in lysates of proliferating, vehicle (DMSO)-treated HMC-1.2 cells showed basal phosphorylation of eIF2 $\alpha$ suggesting constitutive activation of the UPR (Figure 3A). Enforced activation of the UPR by treatment with the glycosylation inhibitor TM resulted in enhanced eIF $2 \alpha$ phosphorylation, indicating that the output of PERK was not maxed in proliferating HMC-1.2 cells (Figure 3A). Using RT-qPCR we found that $C H O P$ mRNA was markedly enhanced after $24 \mathrm{~h}$ in TM-treated HMC-1.2 cells, which was significantly reduced by the PERK inhibitor GSK2606414 (Figure 3B). Treatment with $0.1 \mu \mathrm{M}$ GSK2606414 resulted in a near to maximum suppression of TM induced $C H O P$ mRNA production (Figure $3 \mathrm{~B}$ ) as well as corresponding eIF2 $\alpha$ phosphorylation (Supplementary Figure 3). Having identified the effective concentrations of GSK2606414, we next investigated if blocking PERK activity might inhibit proliferation of HMC-1.2 cells. Hence, cells were treated with increasing concentrations of GSK2606414 (0.01 $-1 \mu \mathrm{M})$ or vehicle and cell numbers were determined every $24 \mathrm{~h}$ using an analytical cell counter. Inhibition of PERK had no significant effect on proliferation of HMC1.2 cells after $72 \mathrm{~h}$ treatment (Figure $3 \mathrm{C} \& 3 \mathrm{D}$ ). This was corroborated by XTT assays measuring metabolic activity (Figure 3E) as well as by analysis of apoptosis/cell death in GSK2606414-treated cells by staining with annexin V and propidium iodide (AV/PI) (Figure 3F). In conclusion, the PERK pathway of the UPR appears slightly active in proliferating HMC-1.2 cells, however, an involvement in proliferation and survival, in comparison to the IRE1 $\alpha /$ $\mathrm{XBP} 1 \mathrm{~s}$ pathway, was not observed. 
A

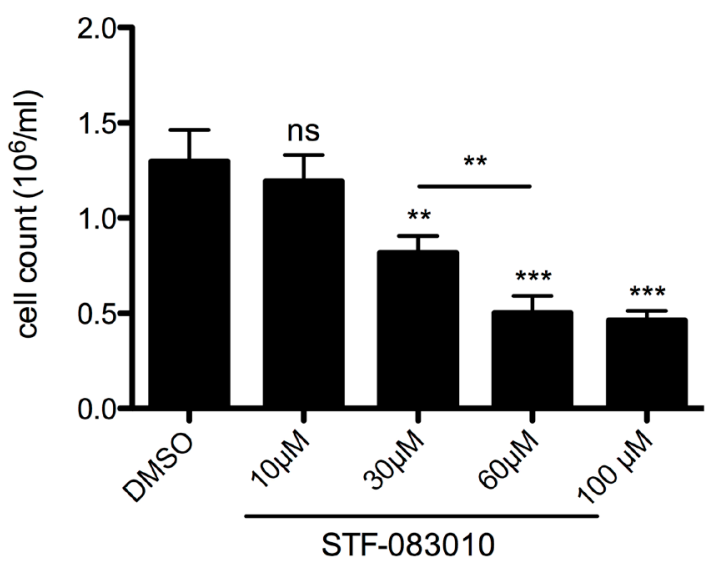

C

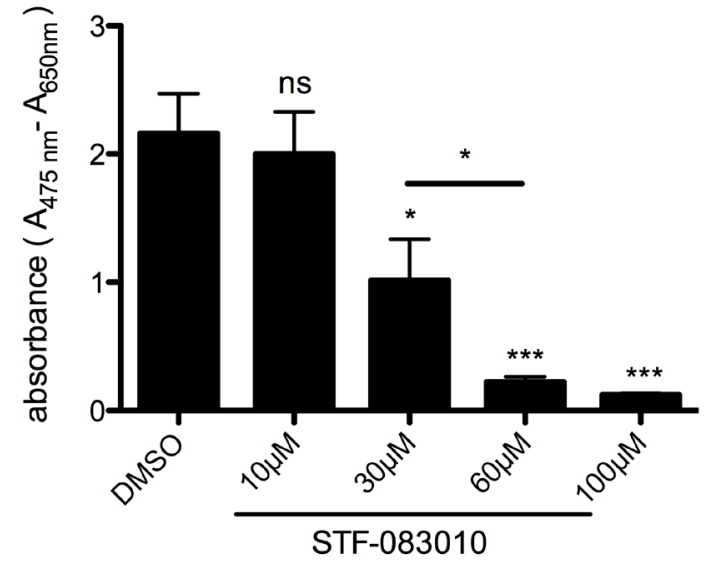

$\mathbf{E}$

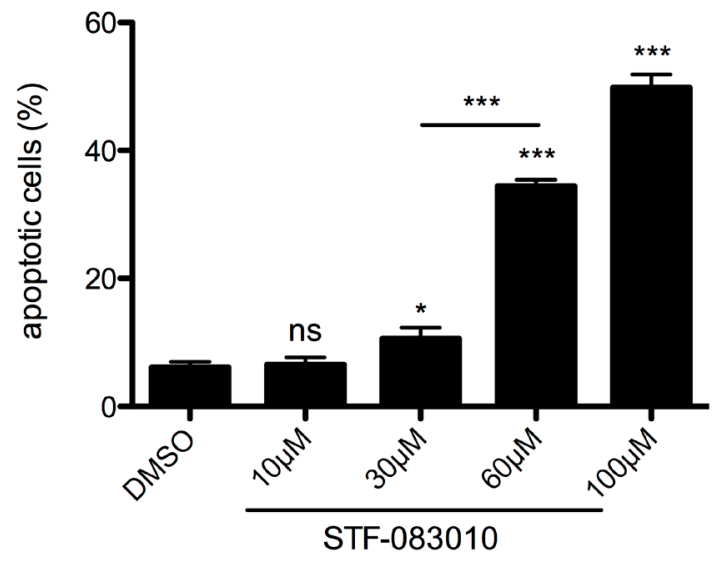

B

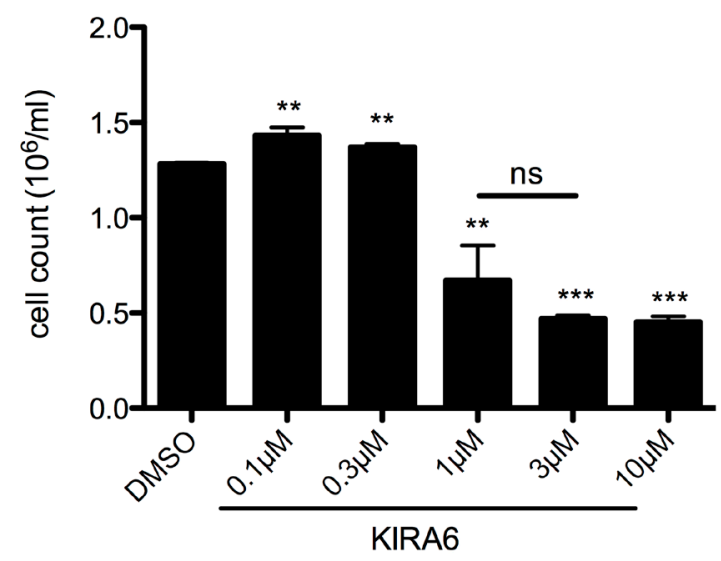

D

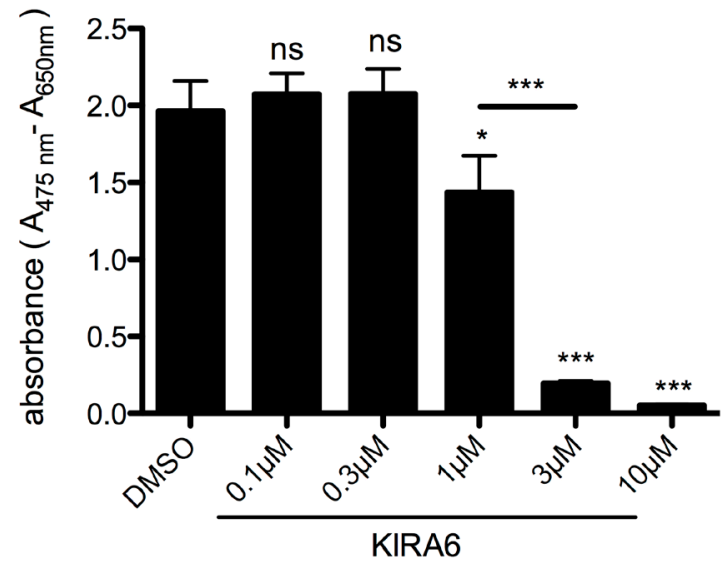

$\mathbf{F}$

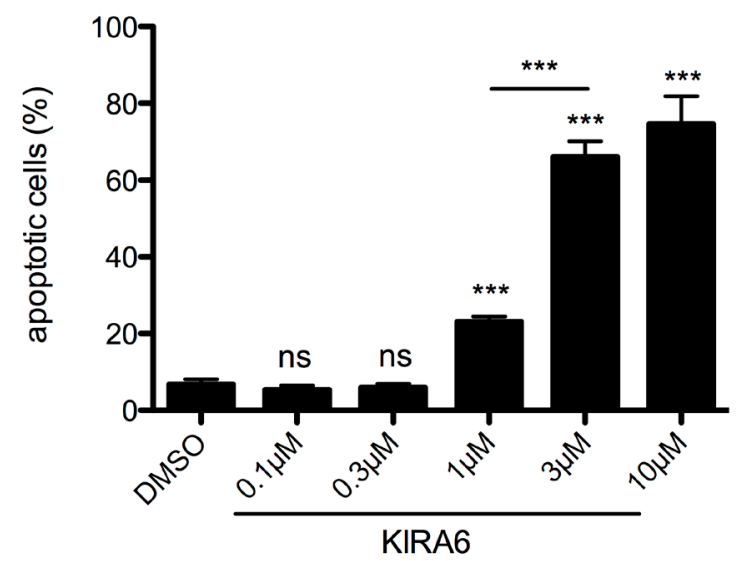

Figure 2: IRE1 $\alpha$ endonuclease and kinase inhibition restrains proliferation and survival of HMC-1.2. A, B. Proliferation was measured by Casy cell counter after $72 \mathrm{~h}$. HMC-1.2 cells were treated for $72 \mathrm{~h}$ with vehicle (DMSO) or with the indicated concentrations of STF-083010 (STF) (A, n=4) or KIRA6 (B, n=3). C, D. Metabolic activity after 72h treatment with indicated concentrations of STF (C, $\mathrm{n}=3$ ) or KIRA6 (D, n=3) was measured by an XTT proliferation kit. E. Cell viability after $72 \mathrm{~h}$ treatment with indicated concentrations of STF (E, n=3) or KIRA6 ( $F, n=3$ ) was measured by FACS analysis of Annexin V/ propidium iodide stained HMC-1.2 cells. Data shown are mean $\pm \mathrm{SD}$ from $\mathrm{n} \geq 3$ independent experiments. Student's $t$-Test and one-sample $t$-Test were performed to calculate the p-values. ${ }^{*} p<$ $0.05, * * p<0.01, * * * p<0.001$. 

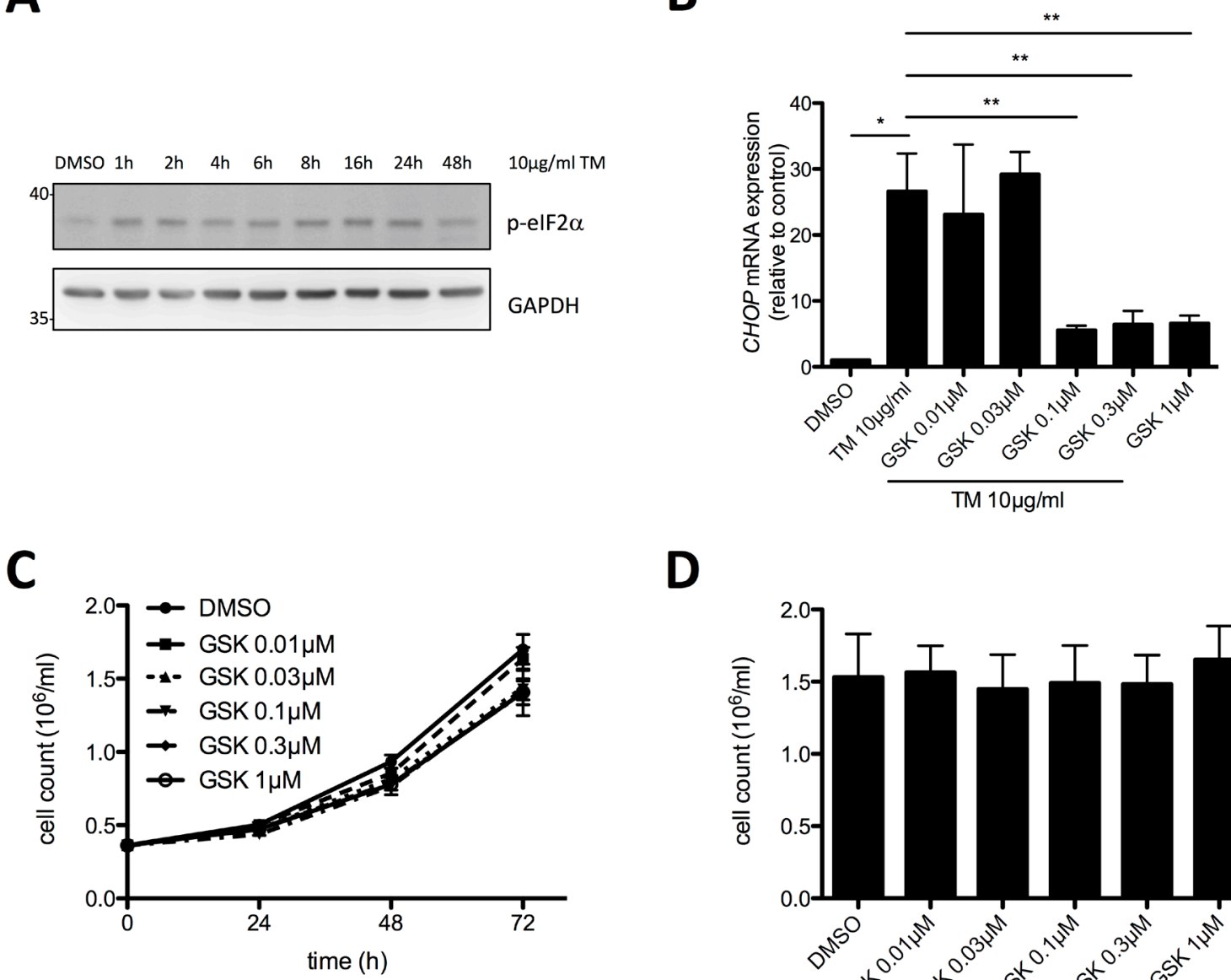

D

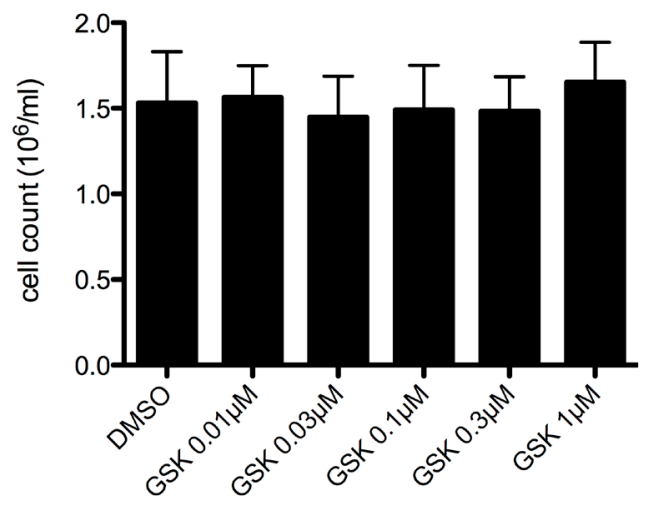

$\mathbf{E}$

$\mathbf{F}$
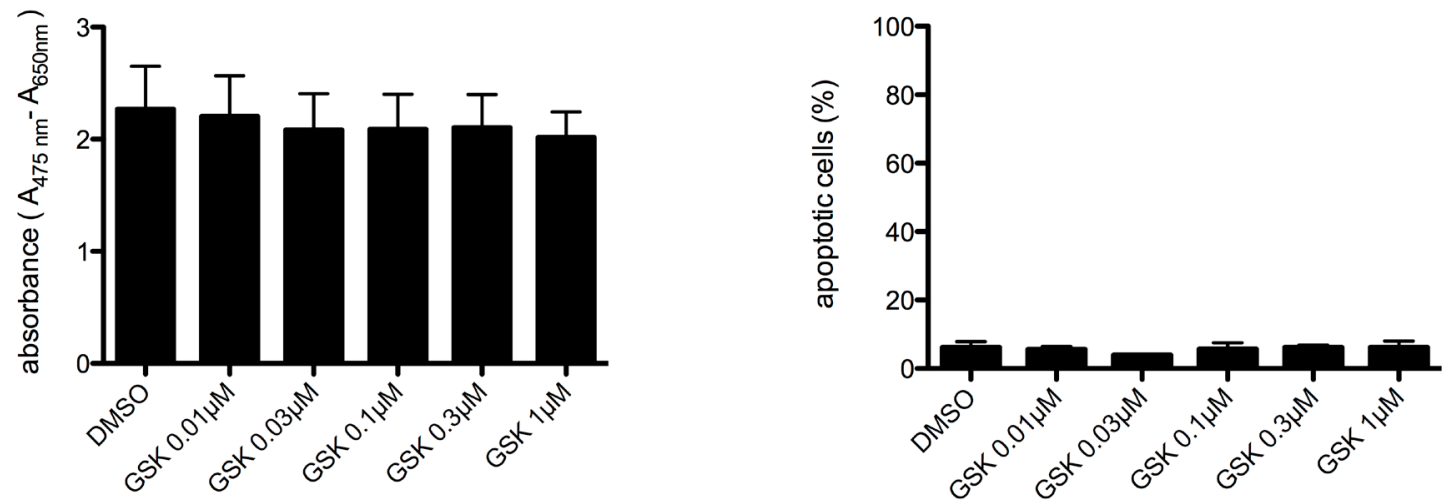

Figure 3: Proliferation and survival of HMC-1.2 cells is independent on PERK pathway activation. A. HMC-1.2 cells were treated with vehicle (DMSO) or $10 \mu \mathrm{g} / \mathrm{ml} \mathrm{TM}$ for the indicated time points and phosphorylation of elF2 $\alpha$ was detected by Western blot. GAPDH served as loading control. B. Inhibition of TM-induced CHOP expression by GSK2606414 (GSK) was evaluated by RTqPCR. HMC-1.2 cells were pretreated for $1 \mathrm{~h}$ with vehicle (DMSO) or the indicated concentrations of GSK followed by TM treatment for 6h. $C H O P$ mRNA expression was normalized to HPRT. $(\mathrm{n}=3) \mathbf{C}$. Impact of GSK on HMC-1.2 proliferation was measured by automated Casy cell counter every $24 \mathrm{~h}$ for up to $72 \mathrm{~h}$. HMC-1.2 cells were treated for $72 \mathrm{~h}$ with vehicle (DMSO) or with the indicated concentrations of GSK. Proliferation graphs of a representative experiment are shown. D. Statistical analysis of cell counts after $72 \mathrm{~h}$ of independent experiments as measured in C. ( $\mathrm{n}=3)$ E. Effect of the indicated concentrations of GSK on metabolic activity after $72 \mathrm{~h}$ was measured by an XTT proliferation kit. $(\mathrm{n}=3) \mathbf{F}$. Cell viability was measured by FACS analysis of Annexin V/ propidium iodide stained HMC-1.2 cells treated for $72 \mathrm{~h}$ with vehicle (DMSO) or the indicated concentrations of GSK. $(\mathrm{n}=3)$ Data shown are mean $\pm \mathrm{SD}$ from $\mathrm{n} \geq 3$ independent experiments. Student's $t$-Test and one-sample $t$-Test were performed to calculate the p-values. ${ }^{*} p<0.05,{ }^{* *} p<0.01,{ }^{* * *} p<0.001$. 


\section{Proteasome inhibition suppresses proliferation and survival of human MCL cells}

Our data so far demonstrated that survival of HMC1.2 MCL cells is supported by the constitutive activation of the UPR, especially the IRE1 $\alpha$ arm. An important mechanism of cells to cope with rising levels of unfolded proteins is ERAD that depends on a functional ubiquitin proteasome system. Proteasome inhibitors, particularly the FDA-approved BZ (Velcade, originally codenamed PS-341), are used in MM cells and patients to block the ERAD resulting in enhanced accumulation of (misfolded) proteins in the ER, and thus to induce terminal UPR [35, 36]. On the other side, various cancer cell lines have been shown to be resistant to BZ [37]. Thus, the possibility to reduce HMC-1.2 proliferation and survival by $\mathrm{BZ}$ treatment was thoroughly investigated. Measurement of total protein ubiquitination by immunoblotting of whole-cell lysates with ubiquitin-specific antibodies as readout for proteasome inhibition, proved $10 \mathrm{nM} \mathrm{BZ}$ to be sufficient for an optimal response (Figure 4A). Moreover, $10 \mathrm{nM}$ BZ triggered significant activation of the IRE1 $\alpha$ path of the UPR as measured by RT-qPCR of XBP1s (Figure 4B). Accordingly, BZ-induced $X B P 1 s$ generation was suppressed by STF-083010 and KIRA6 (Figure 4B). Next, proliferation of HMC-1.2 cells in the absence or presence of BZ was analyzed. Treatment with $5-30 \mathrm{nM}$ BZ for 24-72h was found to completely block proliferation (Figure 4C \& 4D). This was in agreement with the suppression of metabolic activity measured by XTT assay, which suggested induction of cell death by BZ treatment (Figure 4E). Hence, by determining AV/PI doublepositivity, BZ-triggered cell death was analyzed. Indeed, BZ was a potent inducer of HMC-1.2 cell death with 10 and $30 \mathrm{nM}$ causing approximately $40 \%$ and $80 \%$ doublepositive cells, respectively (Figure 4F; Supplementary Figure 1D). Thus, our data suggest that comparable to MM [35], BZ-mediated proteasome inhibition might be usable as a therapeutic option in KIT ${ }^{\mathrm{D} 816 \mathrm{~V}}$-positive MCL.

\section{Inhibition of BZ-induced JNK activity synergistically promotes cell death of HMC-1.2 MCL cells}

The stress kinase JNK has been shown to be activated in response to proteasome inhibition and to initiate an apoptotic program [38]. On the other hand, JNK has been found in MCs to promote proliferation [39, 40]. Moreover, JNK has been demonstrated in cancer cells to be able to mediate both pro-survival and pro-apoptotic signaling [41]. Providing that BZ treatment of HMC-1.2 cells results in activation of JNK, which might exert a proliferation- and/or survival-promoting role, combined use of proteasome and JNK inhibitors might be used as effective treatment of MCL. To address this question,
HMC-1.2 cells were treated with $10 \mathrm{nM} \mathrm{BZ}$ for $24 \mathrm{~h}$ and phosphorylation of JNK was measured by phosphospecific immunoblotting. Indeed, BZ induced pronounced phosphorylation of JNK, which was manifested in JNK activation since the characteristic JNK target, JUN, was phosphorylated as well (Figure 5A). Inhibition of JNK by the selective pharmacological JNK inhibitor, JNK-IN-8 [42], did not block BZ-induced JNK phosphorylation, but completely suppressed phosphorylation of JUN (Figure $5 \mathrm{~A})$. The markedly retarded electromobility of p-JNK from BZ-vs. BZ/JNK-IN-8-treated cells can be explained by covalent binding of JNK-IN-8 to a conserved Cys residue within JNK [42]. Moreover, BZ treatment caused marked induction of $J U N$ mRNA, which was inhibited by JNK-IN-8 (Figure 5B). The observed equivalence between JNK phosphorylation and activation was not self-evident, because TM treatment of HMC-1.2 cells also induced JNK phosphorylation, however, did not cause phosphorylation of JUN (Figure 5A). This difference coincided with an altered running behavior of $\mathrm{p}-\mathrm{JNK}$ in TM- vs. BZ-treated HMC- 1.2 cells. Next, we analyzed the effect of treatment with JNK-IN-8 on proliferation, metabolic activity, and survival of HMC-1.2 cells. For these experiments, we used $3 \mu \mathrm{M}$ of JNK-IN-8, a concentration that effectively suppressed JUN phosphorylation and JUN mRNA production in response to $\mathrm{BZ}$ (Figure 5A \& 5B). Within 72h, JNK-IN-8 reduced proliferation of HMC-1.2 cells by approximately $40 \%$ (Figure 5C), exerted only a minor effect on metabolic activity (Figure 5D), and did not impact on survival (Figure 5E \& 5F). Intriguingly and confirming our initial assumption that BZ-induced activation of JNK is counteracting induction of cell death of HMC-1.2 cells, the combination of $3 \mu \mathrm{M}$ JNK-IN-8 with a very low concentration of BZ $(5 \mathrm{nM})$ resulted in a synergistic increase of cell death compared to $\mathrm{BZ}$ alone (Figure 5E \& 5F). In conclusion, enhancing the cytotoxic effect of BZ-induced proteasome inhibition with concomitant JNK suppression by JNK-IN-8 might have the potential as a novel effective therapy for patients suffering from MCL.

\section{IRE1 $\alpha$ mediates BZ-induced $J U N$ and $C H O P$ transcription}

Via a complex with the adaptor protein TRAF2, IRE1 $\alpha$ was demonstrated to activate JNK [43]. Moreover, in acute myeloid leukemia JUN was recently found to be involved in the transcription of the UPR transcription factors XBP1 and ATF4 [44]. As shown before, in comparison to TM, BZ induced strong production of JUN mRNA and pretreatment with the selective JNK inhibitor JNK-IN-8 suppressed BZ-induced JUN transcription (Figure 6A). Interestingly, the IRE1 $\alpha$ kinase/endonuclease inhibitor KIRA6 significantly reduced $J U N$ production, whereas STF-083010, being an endonuclease inhibitor 
A

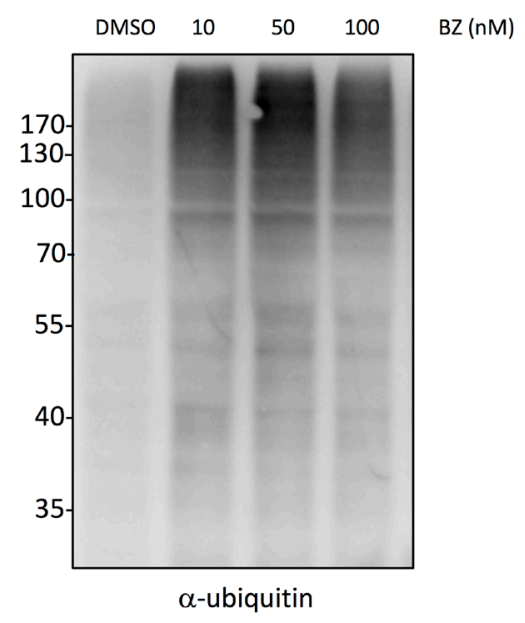

C

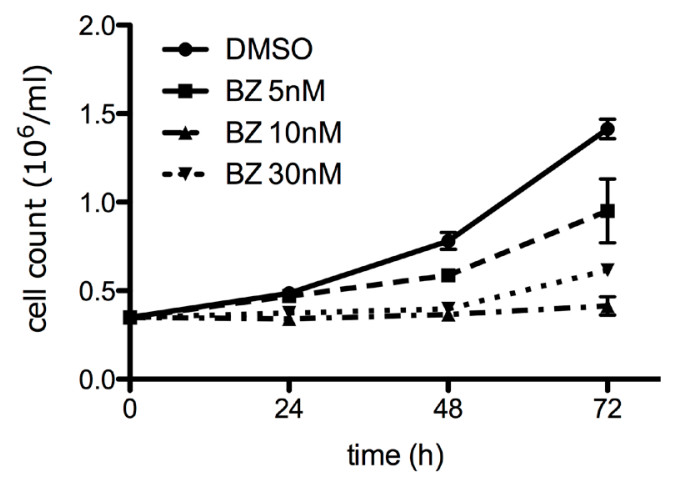

$\mathbf{E}$

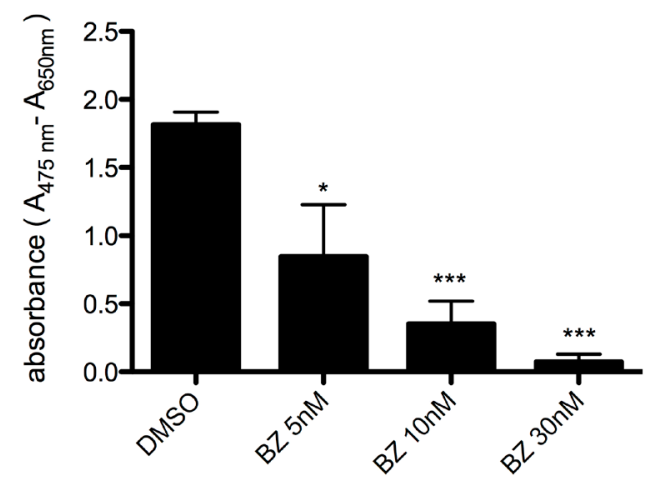

B
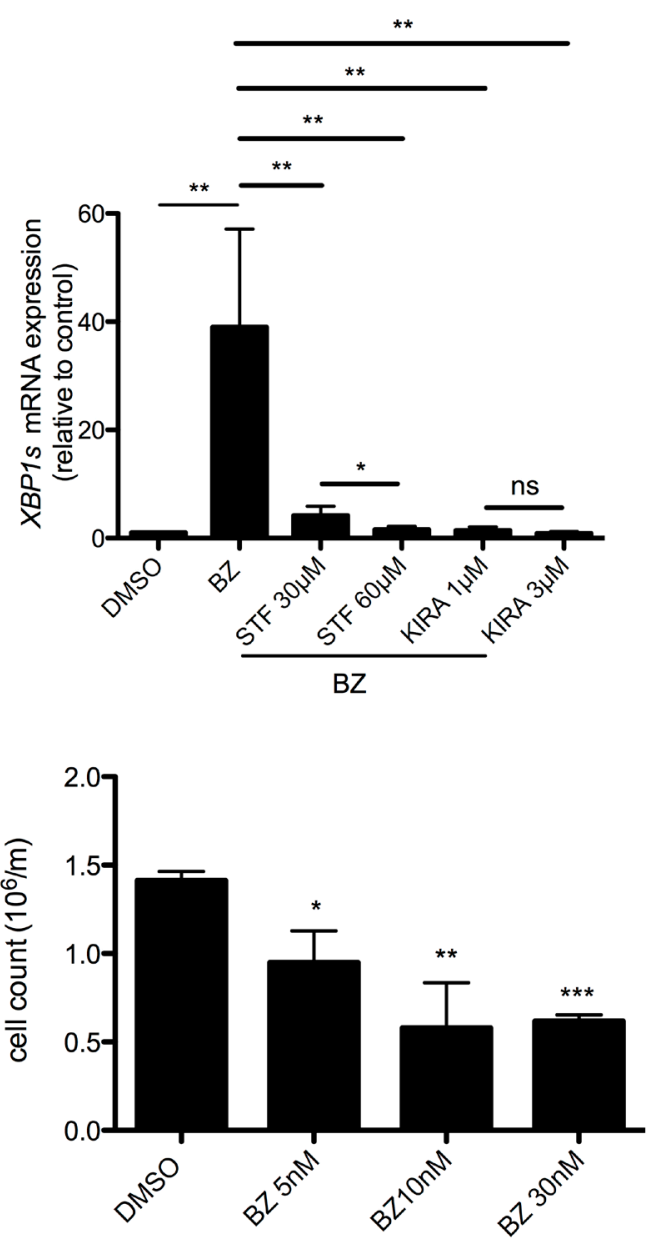

$\mathbf{F}$

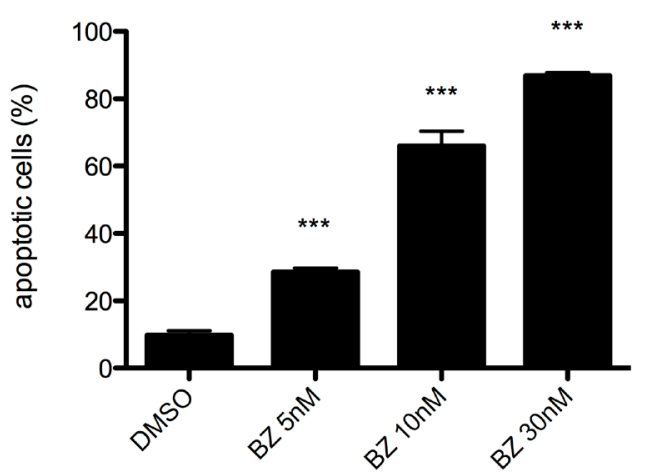

Figure 4: Proteasome inhibitor bortezomib suppresses proliferation and survival of HMC-1.2 cells. A. Bortezomib (BZ) induced pan-ubiquitination of proteins (shown as smear) in $\mathrm{HMC1.2}$ cells after $24 \mathrm{~h}$ treatment with the indicated concentrations. Ubiquitination was detected by Western blotting. B. HMC-1.2 cells were treated with vehicle (DMSO) or STF or KIRA6 for 60min followed by a $30 \mathrm{nM} \mathrm{BZ}$ treatment for 24h. XBP1s mRNA expression was measured by RT-qPCR and normalized to HPRT. (n=5) $\mathbf{C}$. Proliferation was measured by Casy cell counter every $24 \mathrm{~h}$ for up to $72 \mathrm{~h}$. HMC-1.2 cells were treated with vehicle (DMSO) or with the indicated concentrations of BZ. Proliferation graphs of a representative experiment is shown. D. Statistical analysis of cell counts after $72 \mathrm{~h}$ of independent experiments as measured in C. ( $\mathrm{n}=3)$ E. Metabolic activity was measured by XTT assay after $72 \mathrm{~h}$ treatment with the indicated concentrations of BZ (or vehicle). F. Cell viability was measured by FACS analysis of Annexin V/ propidium iodide stained HMC-1.2 cells treated for 72h with vehicle (DMSO) or the indicated concentrations of BZ. ( $\mathrm{n}=3$ ) Data shown are mean $\pm \mathrm{SD}$ from $\mathrm{n} \geq 3$ independent experiments. Student's $t$-Test and one-sample $t$-Test were performed to calculate the p-values. ${ }^{*} p<0.05,{ }^{* *} p<0.01,{ }^{* * *} p<$ 0.001 . 
A

DMSO DMSO DMSO JNK-IN JNK-IN

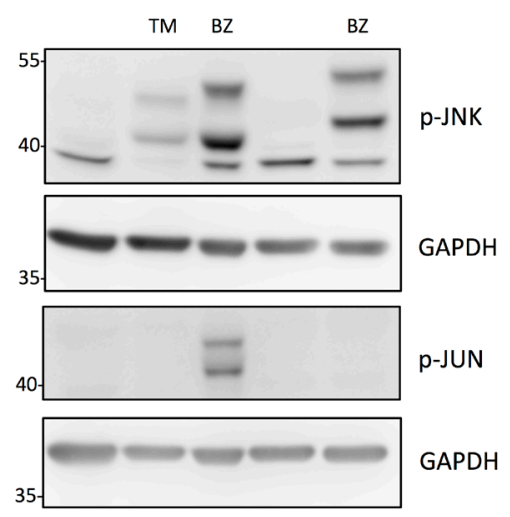

C

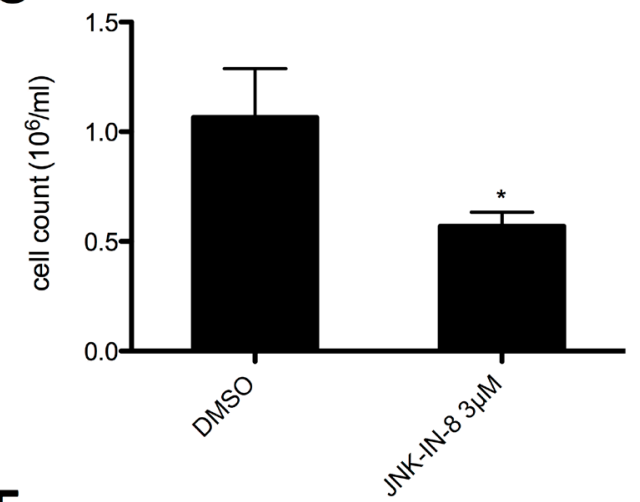

$\mathbf{E}$
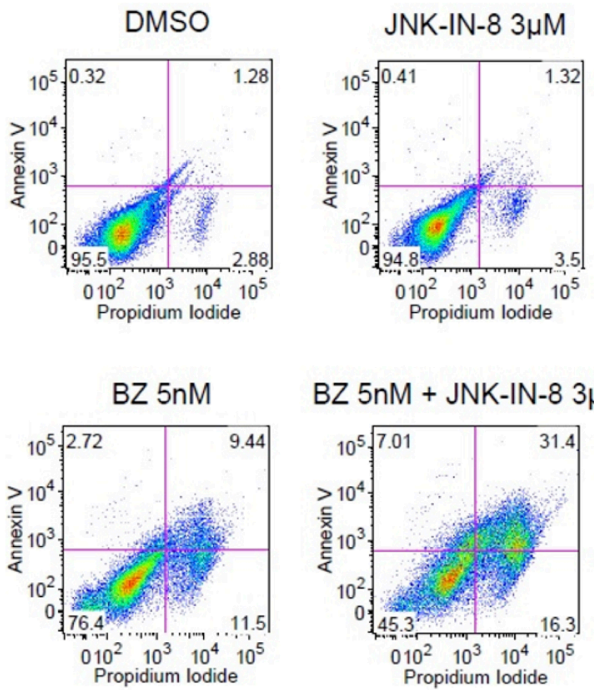

B

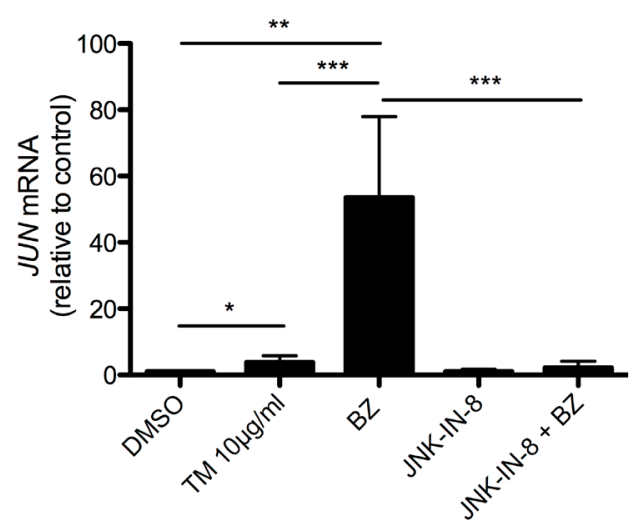

D

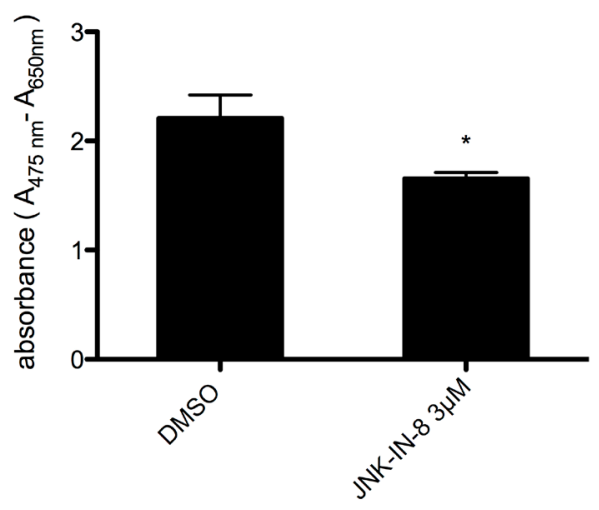

$\mathbf{F}$

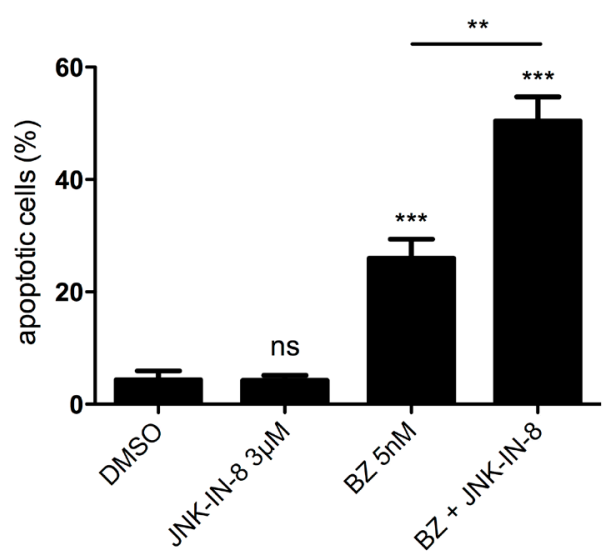

Figure 5: Synergistic induction of cell death by a combination of low dose BZ with JNK-IN-8. A. HMC-1.2 cells were preincubated with vehicle (DMSO) or JNK-IN-8 for $1 \mathrm{~h}$ followed by TM $(10 \mu \mathrm{g} / \mathrm{ml})$ or BZ $(10 \mathrm{nM})$ treatment for $24 \mathrm{~h}$. Phosphorylation of JNK and JUN was detected by Western blotting. GAPDH served as loading control. $(\mathrm{n}=3)$ B. HMC-1.2 cells were pretreated for $1 \mathrm{~h}$ with vehicle (DMSO) or JNK-IN-8 $(3 \mu \mathrm{M})$ followed by a $24 \mathrm{~h}$ BZ treatment. $J U N$ mRNA expression was evaluated by RT-qPCR and normalized to HPRT. $(\mathrm{n}=4) \mathbf{C}, \mathbf{D}$. HMC-1.2 cells were treated with DMSO or $3 \mu \mathrm{M}$ JNK-IN-8 for $24 \mathrm{~h}$ and proliferation (Casy cell counting) C $(\mathrm{n}=4)$ and metabolic activity (XTT assay) D ( $\mathrm{n}=3$ ) were measured. E. Cell viability was determined by FACS analysis of Annexin V/ propidium iodide stained HMC-1.2 cells treated for $72 \mathrm{~h}$ with the indicated substances. One representative experiment is shown. F. Statistical analysis of the amount of apoptotic cells after $72 \mathrm{~h}$ of independent experiments as measured in $\mathrm{E}$. (n=3) Data shown are mean $\pm \mathrm{SD}$ from $\mathrm{n} \geq 3$ independent experiments. Student's $t$-Test and one-sample $t$-Test were performed to calculate the $p$-values. ${ }^{*} p<0.05,{ }^{* *} p<0.01,{ }^{* * *} p<0.001$. 
A

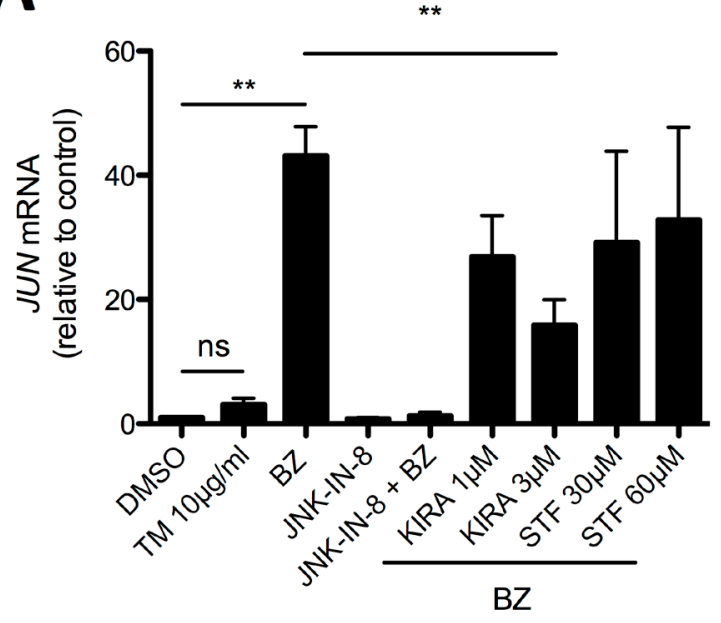

C

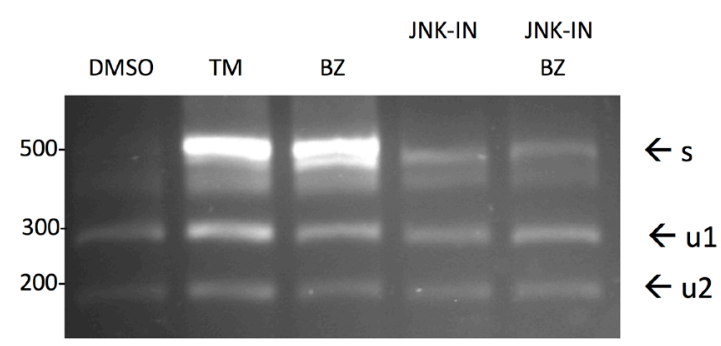

E

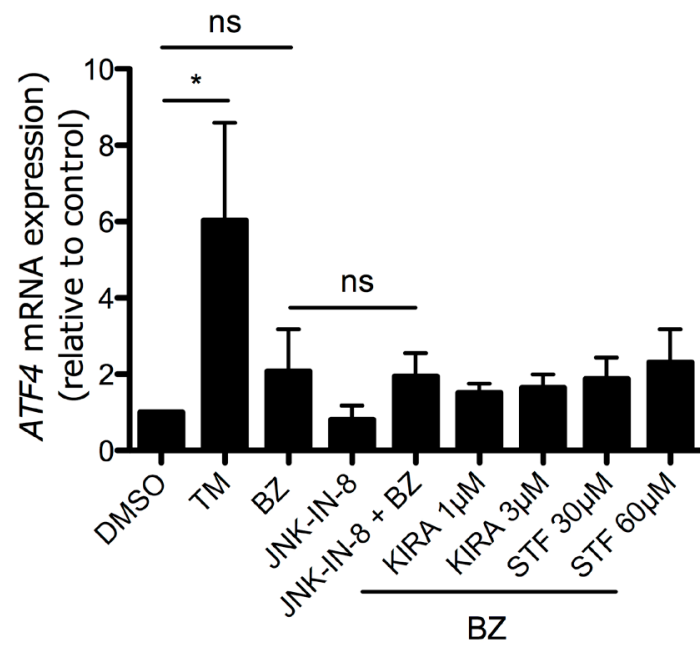

B

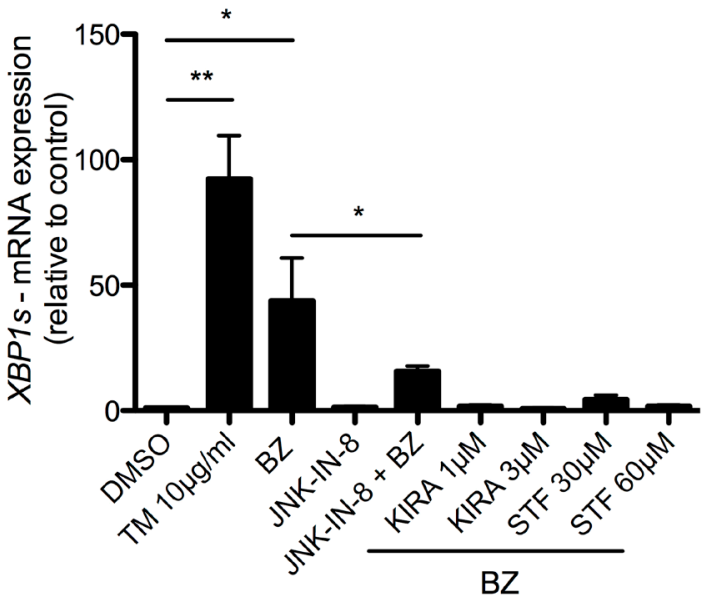

D

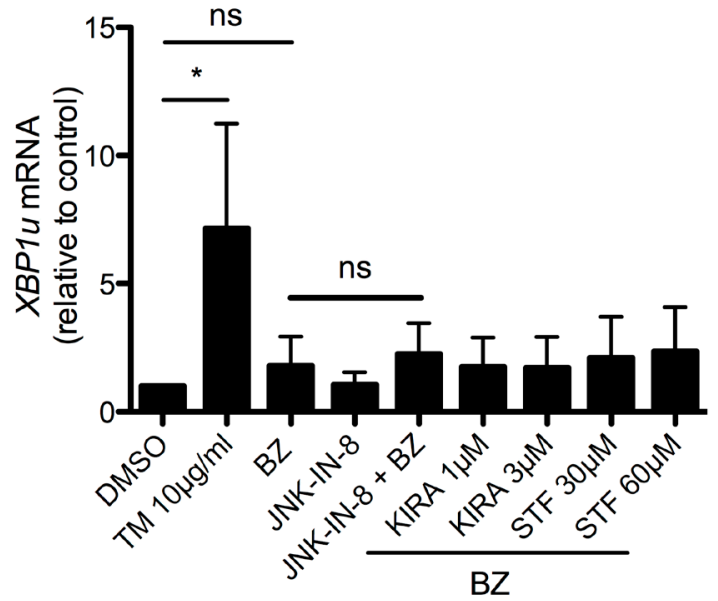

$\mathbf{F}$

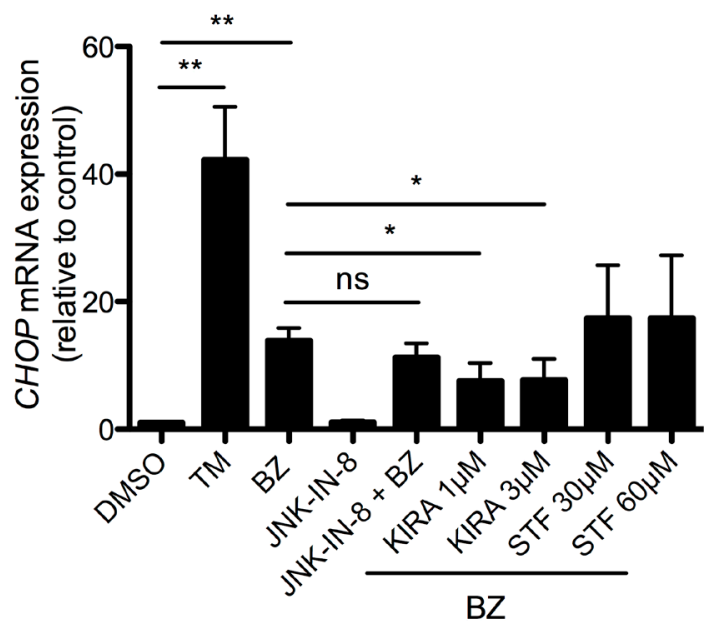

Figure 6: JNK signaling is involved in XBP1 splicing. A, B, D, E, F. HMC-1.2 cells were pretreated for 1h with vehicle (DMSO) or indicated concentrations of the inhibitors JNK-IN-8, KIRA6 or STF followed by a $30 \mathrm{nM}$ BZ treatment for $24 \mathrm{~h}$. JUN A, XBP1s B, XBP1u D, ATF4 E, and CHOP F mRNA expression was evaluated by RT-qPCR and normalized to HPRT. (n=4) C. Expression of spliced XBP1 mRNA was evaluated by spliced XBPI assay as in Figure 2A. Data shown are mean \pm SD from $\mathrm{n} \geq 3$ independent experiments. Student's $t$-Test and one-sample $t$-Test were performed to calculate the $p$-values. $* p<0.05, * * p<0.01, * * * p<0.001$. 
only, was unable to attenuate $J U N$ transcription (Figure $6 \mathrm{~A})$. This suggested that IRE $1 \alpha$, via its kinase activity, is directly involved in the activation of the JNK/JUN pathway. Next, we analyzed if JNK is involved in the transcription as well as splicing of $X B P 1$. BZ treatment of HMC-1.2 cells caused the production of $X B P 1 s$ mRNA, which was significantly reduced by pre-incubation with JNK-IN-8 (Figure 6B). These RT-qPCR data were corroborated employing the $X B P 1$ mRNA splicing assay (Figure 6C). This assay, in addition to $X B P 1 s$, allows the evaluation of changes in XBPIu. However, no obvious differences in the amounts of $X B P 1 u$ were observed between BZ-treated cells pre-incubated with vehicle (DMSO) or JNK-IN-8 (Figure 6C), indicating involvement of JNK in splicing rather than production of $X B P 1$ in $\mathrm{BZ}$ treated HMC-1.2 cells. This was verified measuring the amount of XBPI $u$ mRNA using RT-qPCR (Figure 6D). Finally, the role of IRE1 $\alpha$ and JNK with respect to BZinduced ATF4 and $C H O P$ transcription was investigated. Interestingly, compared to TM treatment, BZ did not cause a significant induction of ATF4 mRNA; this was not influenced by pharmacological blockade of JNK or IRE1 $\alpha$ (Figure 6E). This is in agreement with data by Nawrocki et al., who demonstrated PERK inhibition by BZ treatment in pancreatic cancer cells [37]. Unexpectedly and in contrast to $A T F 4, \mathrm{BZ}$ did induce transcription of $\mathrm{CHOP}$, though less pronounced than TM. This induction was weakly, but significantly attenuated by KIRA6, however not by STF083010 and JNK-IN-8, suggesting a JNK-independent function of the activated IRE1 $\alpha$ kinase domain (Figure $6 \mathrm{~F})$. So far, we cannot exclude participation of ATF6 in BZ-triggered $C H O P$ transcription $[45,46]$. In conclusion, $\mathrm{JNK}$ is mainly involved in BZ-induced $X B P 1 s$ production and hence promotion of proliferation and survival, causing enhanced vulnerability for combined BZ and JNK-IN-8 treatment.

\section{DISCUSSION}

For cancer therapy, both blockade of adaptive UPR as well as exaggeration of ER stress resulting in terminal UPR might be employed. Our data concentrating on MCL and utilizing the $\mathrm{KIT}^{\mathrm{V} 560 \mathrm{G}, \mathrm{D} 816 \mathrm{~V}}$-positive MCL cell line HMC-1.2 as a model showed for the first time the efficacy of both approaches with respect to induction of cytostatic and/or cytotoxic responses. Inhibition of the IRE1 $\alpha$ arm of the UPR by different types of inhibitors (MKC-8866, STF-083010, and KIRA6) suppressed proliferation at concentrations needed for blockade of IRE1 $\alpha$-mediated $X B P 1$ splicing. At higher concentrations, these inhibitors triggered apoptosis by terminal UPR. Enhanced activation of the UPR by proteasome inhibition, which blocks the ERAD pathway and promotes the excessive accumulation of proteins in the ER, caused a marked cytotoxic response. Additional inhibition of the compensating activation of the kinase JNK allowed for synergistic induction of cell death at comparatively low inhibitor concentrations. Hence, our data suggest that the UPR can be addressed as an attractive and effective therapeutic target against $\mathrm{KIT}^{\mathrm{D} 816 \mathrm{~V}}$-positive MCL. Comparable low (2-10 nM), pharmacologically achievable concentrations of BZ were already shown to suppress growth of MM cells as well as to sensitize them to conventional chemotherapeutic agents [35, 47].

Cells of the plasma cell neoplasm, MM, are dependent on a functioning IRE1 $\alpha / \mathrm{XBP} 1$ arm of the UPR. Inhibition of the RNase activity of IRE1 $\alpha$ by the small-molecule inhibitor STF-083010 was demonstrated to have cytotoxic activity against human MM cells in a xenograft model as well as ex vivo [33]. Moreover, the covalent IRE1 $\alpha$ inhibitor $4 \mu 8 \mathrm{C}$ attenuated growth of $\mathrm{MM}$ cell lines, however, was not associated with acute toxicity [48]. Enhancing ER stress by blocking proteasome activity using BZ (PS-341) was shown to be cytostatic and cytotoxic to human MM cell lines as well as freshly isolated patient MM cells [35]. BZ treatment lead to $X B P 1$ splicing and the IRE1 $\alpha$ inhibitor MKC3946, which, by its sole use, modestly inhibited growth of MM cells, could significantly enhance BZ-induced cell death [49]. Motivated by these reports, we analyzed the importance of the UPR for growth and survival of human MCL cells using the KIT ${ }^{\mathrm{V} 560 \mathrm{G}, \mathrm{D} 816 \mathrm{~V}}$-positive MCL cell line HMC-1.2. Employing three different IRE1 $\alpha$ inhibitors, cytostatic as well as cytotoxic activities could be observed dependent on the inhibitor concentrations applied. These inhibitors were MKC-8866 and STF-083010 blocking the RNase activity of IRE1 $\alpha$ [33] as well as KIRA6, an ATP-competitive IRE1 $\alpha$ kinase inhibitor allosterically coinhibiting IRE1 $\alpha$ 's RNase activity by breaking respective oligomers [34].

Inhibitor concentrations that maximally blocked $X B P 1$ splicing caused strong suppression of HMC-1.2 proliferation, however, only weak cytotoxic effects were observable. On the other hand, concentrations higher than needed for the full blockade of XBP1 splicing were able to induce significant apoptosis. The reason for this qualitative difference, the switch from a cytostatic to a cytotoxic response, has not been clarified yet. One possibility could be the potential need for higher concentrations of IRE1 $\alpha$ inhibitors for the suppression of RIDD. While this cannot be excluded for the two IRE1 $\alpha$ RNase inhibitors, MKC-8866 and STF-083010, it appears rather unlikely for KIRA6 in the light of work from Papa and coworkers [34]. In their experiments, the IC50 of KIRA6 for RIDD inhibition was lower than the IC50 for inhibition of XBP1 splicing. Another possibility might be cytotoxic side effects of these inhibitors at higher concentrations. KIRA6 as an ATP-competitive inhibitor might additionally block other kinases possibly involved in pro-survival signaling. Indeed, our data indicate that KIRA6, either directly or indirectly, is able to suppress phosphorylation/activation of JNK. Moreover, all three inhibitors, at higher concentrations, might interact with 
completely different targets causing pro-apoptotic signals. The principle variability of inhibitors has previously been shown convincingly by Rix et al, who found by chemical proteomic profiling that the oxidoreductase NQO2 is inhibited at physiologically relevant concentrations by the otherwise rather selective tyrosine kinase inhibitors, imatinib and nilotinib [27]. A further example of IRE1 $\alpha$-independent KIRA6 activity might underlie the small, though significant pro-proliferative effect of low concentrations of this IRE1 $\alpha$ inhibitor (Figure 2B). At this point, the involved target of KIRA6 is not known. Ghosh et al. tested a panel of seven Ser-/Thr-kinases for potential cross-reactivity of KIRA6 [34]. Among these kinases only IRE1 $\alpha$ was inhibited in in vitro kinase assays. However, the human kinome is considerably bigger and it cannot be excluded that one or more of the many non-tested kinases i) can be inhibited by KIRA6 and ii) has anti-proliferative effects. At higher concentrations of KIRA6, the measured pro-proliferative effect would then be outcompeted by the pro-apoptotic effect of complete IRE $1 \alpha$ inhibition and suppression of XBP1s expression.

After demonstrating the suitability of inhibition of an adaptive UPR with respect to suppression of MCL cell proliferation and induction of cell death, we next sought to address the possibility of switching an adaptive to a terminal UPR. To reach this, we applied the 26S proteasome inhibitor BZ [50], and found marked triggering of an apoptotic response at reasonable low inhibitor concentrations, which were also found active in the treatment of MM cells [35]. Interestingly, proteasome inhibition has been demonstrated to induce phosphorylation/activation of the MAPK JNK [51,
52], which promoted the cytotoxic response ignited by blockade of the proteasome. In MCs, however, JNK has been found to promote proliferation $[39,40]$. In addition, pro-survival SOX4-dependent upregulation of JNK1 (MAPK8) was demonstrated as a critical factor in acute lymphoblastic leukemia [53]. We hypothesized that BZinduced JNK activation might be compensatory for the MCL cells and additional inhibition of JNK could thus result in enhanced, synergistic cell death of MCL cells. Indeed, combined use of BZ and the selective JNK inhibitor JNK-IN-8 was most effective in causing cell death of HMC-1.2 cells, indicating that in the case of MCL, proteasome inhibition causes pro-proliferative/ anti-apoptotic JNK activation. Since active JNK was able to induce $J U N$ transcription as well as JUN production in HMC-1.2 cells, a pro-survival role of JUN might be envisaged. Interesting in this respect is a recent publication by Zhou et al., who showed a pro-survival role of JUN in acute myeloid leukemia, multiple subtypes of which frequently overexpress JUN [44]. JUN was demonstrated to bind to promoters of several UPR effectors, such as XBP1 and ATF4. However, in HMC-1.2 cells ATF4 upregulation upon BZ treatment was not observed; moreover, inhibition of JNK did not affect expression of XBPlu, suggesting cell type-specific regulatory mechanisms in the UPR.

Interestingly, our data in HMC-1.2 cells hint at a mutual functional dependence of IRE $1 \alpha$ and JNK. While the kinase activity of IRE $1 \alpha$ promotes activation of JNK, JNK appears to be able to facilitate the endonuclease activity of IRE1 $\alpha$ (Figure 7). JNK has been reported to specifically phosphorylate serine and threonine residues,

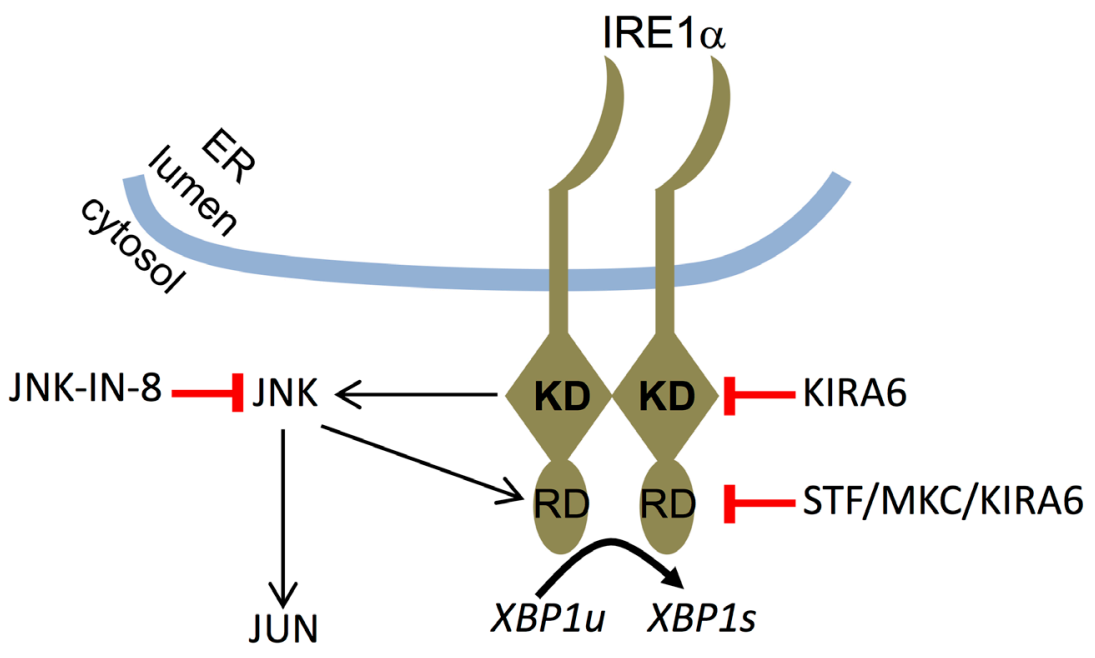

Figure 7: Model of functional interaction between IRE1 $\alpha$ and JNK. Upon recognition of unfolded proteins in the ER lumen, IRE1 $\alpha$ is activated via oligomerization. Its kinase domain (KD) contributes to the activation of its RNase domain (RD) resulting in splicing of XBPI $u$ to yield XBP1s. Moreover, the IRE1 $\alpha$ KD mediates activation of the JNK pathway with JNK, in turn, controlling the activity of the IRE1 $\alpha$ RD. The targets of the pharmacological inhibitors used in this study are indicated. 
which are followed by a proline residue. In several JNK targets, such as in JUN and JUND, proline is followed by an acidic amino acid [54]. Intriguingly and in line with the proposed model (Figure 7), T973 in the endonuclease domain of IRE1 $\alpha$ has been reported to be phosphorylated [55] and resides in the context of the sequence T-P-D and thus would fulfill both location in the endonuclease domain and presence of a JNK target-specific sequence. It will be important to explore the phosphorylation of T973 by JNK and further analyze the IRE1 $\alpha$ (kinase) - JNK IRE1 $\alpha$ (endonuclease) circuit in further leukemia cells.

Similar to the IRE1 $\alpha$ arm of the UPR, the PERK arm, depending on the strength of ER stress, is able to induce both an adaptive and a terminal response. The respective adaptive response involves phosphorylation of eIF $2 \alpha$ preventing the formation of the ternary initiation complex consisting of unphosphorylated eIF $2 \alpha$, GTP, and tRNA ${ }^{\mathrm{Met}}$, thus inhibiting general protein synthesis. The terminal response involves selective translation of the transcription factor ATF4 resulting, amongst others, in the induction of the proapoptotic transcription factor CHOP. ATF4 has also been shown recently to induce autophagy [56]. In case of increased production of mutated or misfolded proteins in the ER, as it may occur in neurodegenerative diseases, blockade of translation by eIF $2 \alpha$ phosphorylation appears appropriate; however, such response would not be advantageous for proliferating leukemia cells. Although we detected basal phosphorylation of eIF $2 \alpha$ in HMC-1.2 cells, pharmacological inhibition of PERK by GSK2606414 did neither have cytostatic nor cytotoxic effects. Speaking against basal PERK activation, GSK2606414 suppressed increased eIF2 $\alpha$ phosphorylation in response to TM treatment, however, it did not reduce basal phosphorylation of eIF $2 \alpha$, suggesting involvement of other kinases, like PKR or mGCN2. Moreover, as with every measurable phosphorylation event, which is the net result of kinase and phosphatase activities, eIF $2 \alpha$-specific phosphatases might be active in MCL cells to allow for protein production as well as to prevent ATF4/CHOPmediated apoptosis. Further analysis of these phosphatases and their regulation in $\mathrm{HMC}-1.2$ cells might enable the identification of novel drug targets in MCL.

In conclusion, we have demonstrated the importance of the UPR for the proliferation and survival of MCL cells, in particular the IRE1 $\alpha$-dependent arm of the UPR. We have shown that both pharmacological inhibition of IRE $1 \alpha$ catalytic activities and exaggeration of the UPR by pharmacological stressors suppress proliferation and survival of MCL cells. Moreover, prosurvival JNK activity induced by BZ-triggered IRE $1 \alpha$ activation is introduced as an additional drug target to boost the efficacy of BZinduced MCL cell death. In conclusion, our data suggest that the UPR can be addressed as an effective therapeutic target against so far unsatisfactorily treatable $\mathrm{KIT}^{\mathrm{D} 816 \mathrm{~V}}$ positive MCL.

\section{MATERIALS AND METHODS}

\section{Cell culture}

HMC-1.2 (KIT $\left.{ }^{\mathrm{V} 560 \mathrm{G}, \mathrm{D} 816 \mathrm{~V}}\right)$ cells were kindly provided by Dr. J. Butterfield (Mayo Clinic, Rochester, MN) [57]. They were maintained in RPMI 1640 medium (Gibco, Thermo Fisher Scientific) supplemented with 10\% fetal bovine serum (FBS), Hepes 1M, pH 7.0-7.6, and 10.000 units penicillin $+10 \mathrm{mg} / \mathrm{ml}$ streptomycin (all from SigmaAldrich) in an atmosphere containing $5 \% \mathrm{CO}_{2}$. The medium was renewed twice a week.

\section{Reagents}

Tunicamycin was purchased from Applichem, Bortezomib from Selleckchem, STF-083010 from Axon Medchem, KIRA6 from Cayman, and GSK2606414 as well as JNK-IN-8 from Calbiochem. DMSO was obtained from Carl Roth $\mathrm{GmbH} \& \mathrm{Co}$. MKC-8866 was provided by MannKind Corporation, Valencia, CA USA.

\section{Western blotting and antibodies}

Pelleted cells were solubilized with $0.5 \%$ NP-40 and $0.5 \%$ sodium deoxycholate in $4{ }^{\circ} \mathrm{C}$ phosphorylation solubilization buffer [58]. After normalizing for protein content, lysates were supplemented with Lämmli buffer, boiled for 5 minutes at $95^{\circ} \mathrm{C}$ and subjected to SDS-PAGE and subsequent Western blot analysis [59]. The following antibodies $\alpha$-ubiquitin, $\alpha$-p-eIF2 $\alpha$ (Ser51), $\alpha$-p-JNK (Thr183/Tyr185), and $\alpha-p-J U N ~(S e r 63)$ were purchased from Cell Signaling Technology, and $\alpha-G A P D H$ (sc32232) from Santa Cruz.

\section{RNA preparation and quantitative RT-PCR}

RNA from $3 \times 10^{6} \mathrm{HMC}-1.2$ cells was extracted using RNeasy Plus Mini Kit (Qiagen) according to the manufacturer's instructions. Total RNA $(1 \mu \mathrm{g})$ was reverse transcribed using Random hexamers (Roche) and Omniscript Kit (Qiagen) according to the manufacturer's instructions. qPCR was performed on a Rotorgene (Corbett Life Science, now Qiagen) by using SYBR green reaction mix (Bioline \#QT650-02). Expression was normalized to the housekeeper HPRT. The relative expression ratio including primer efficiencies was calculated by the Pfaffl method [60]. Primer sequences and efficiency data were as follows: XBP1s fwd AAC CAG GAG TTA AGA CAG CGC TT, rev CTG CAC CTG CTG CGG ACT, 2.00; CHOP fwd GGA GCA TCA GTC CCC CAC TT, rev TGT GGG ATT GAG GGT CAC ATC, 1.98; JUN fwd TAA TCC AGT CCA GCA ACG GG, rev GTG TTC TGG CTG 
TGC AGT TC, 2.48; HPRT fwd TGA CAC TGG CAA AAC AAT GCA, rev GGT CCT TTT CAC CAG CAA GCT, 2.03, XBP1u fwd CAG CAC TCA GAC TAC GTG CA, rev ATC CAT GGG GAG ATG TTC TGG, 2.02.

\section{Apoptosis assay}

Cells were seeded at a density of $3.5 \times 10^{5}$ cells $/ \mathrm{ml}$ and treated with the indicated substances for $72 \mathrm{~h}$. After treatment cells were incubated with Annexin V-Alexa Fluor 647 (Alexis Biochemicals) in culture medium for $20 \mathrm{~min}$ at RT in the dark. Immediately before analysis by flow cytometry, propidium iodide $(1 \mu \mathrm{g} / \mathrm{ml}$ was added and analyzed on a FACScan (BD Biosciences).

\section{Proliferation assays}

Cells were seeded at a density of $3.5 \times 10^{5}$ cells/ $\mathrm{ml}$ or $5.5 \times 10^{5}$ cells $/ \mathrm{ml}$ (Figure $1 \mathrm{C} / 1 \mathrm{D}$ ) and treated with different concentrations of the test substances; solvent (DMSO)-treated cells served as controls. After a 24h-treatment, cells were resuspended completely and 50 $\mu \mathrm{l}$ from each well was diluted in $10 \mathrm{ml}$ PBS for automated multi-parameter cell counting using a Casy cell counter (Innovatis). Metabolic activity was measured using the XTT Cell Proliferation Kit II (XTT)(Roche). Cells were seeded in microplates at a density of $3.5 \times 10^{5}$ cells/ $\mathrm{ml}$ (suspension culture grade, 96 wells, flat bottom) in a final volume of $100 \mu \mathrm{l}$ culture medium per well in a humidified atmosphere $\left(37^{\circ} \mathrm{C}, 5 \% \mathrm{CO}_{2}\right)$ for $72 \mathrm{~h}$. After the incubation period, $50 \mu \mathrm{l}$ of the XTT labeling mixture was added to each well (final XTT concentration $0.3 \mathrm{mg} / \mathrm{ml}$ ). Incubation of the microplate was for $3-4 \mathrm{~h}$ in a humidified atmosphere (e.g., $37^{\circ} \mathrm{C}, 5 \% \mathrm{CO}_{2}$ ).

Spectrophotometrical absorbance of the samples were measured using a microplate reader. The wavelength used to measure absorbance of the formazan product of the XTT assay was $475 \mathrm{~nm}$ and the reference wavelength was $650 \mathrm{~nm}$. Sample values at $475 \mathrm{~nm}$ were subtracted with medium controls (blanked) resulting in delta blanked values. Total absorbance was calculated by subtraction of delta blanked values $(475 \mathrm{~nm})$ with their reference values at $650 \mathrm{~nm}$. These absorbance values $\left(\mathrm{A}_{475 \mathrm{~nm}}-\mathrm{A}_{650 \mathrm{~nm}}\right)$ are shown in the respective figures.

\section{XBP1 mRNA splicing}

RNA was isolated and reverse transcribed as above to obtain total cDNA. Then, XBP1 primers were used to amplify an XBP1 amplicon spanning the $26 \mathrm{nt}$ intron from the cDNA samples in a regular 3-step PCR. Thermal cycles were: $5 \mathrm{~min}$ at $95{ }^{\circ} \mathrm{C}, 30$ cycles of $30 \mathrm{~s}$ at $95{ }^{\circ} \mathrm{C}$, $30 \mathrm{~s}$ at $60{ }^{\circ} \mathrm{C}$, and $1 \mathrm{~min}$ at $72{ }^{\circ} \mathrm{C}$, followed by $72{ }^{\circ} \mathrm{C}$ for $15 \mathrm{~min}$, and a $4{ }^{\circ} \mathrm{C}$ hold. PCR was performed using h-XBP1.3 fwd: AAA CAG AGT AGC AGC TCA GAC TGC and h-XBP1.12 rev: TCC TTC TGG GTA GAC CTC TGG GAG primers. PCR fragments were then digested by PstI and separated on Ethidium Bromide containing $2 \%$ agarose gels. The restriction digest of unspliced XBP1 (XBP1u) resulted in two fragments of 290 and $183 \mathrm{bp}$. The size of the XBP1s amplicon lacking PstI sites was 473bp.

\section{Statistical analysis}

Data were generated from independent experiments. P-values were calculated by the unpaired two-tailed Student's $t$-test or the one-sample $t$-Test using GraphPad Prism. Figures represent means $\pm \mathrm{SD}$ of $\mathrm{n} \geq 3$ independent experiments (with $\mathrm{n}$ indicated in the respective figure legends). $P$-values of $*<0.05, * *<0.01$, and $* * *<0.001$ were considered statistically significant. Values higher than a $p$-value of 0.05 were regarded as not significant (ns).

\section{Abbreviations}

ATF6: activating transcription factor 6; AV: annexin V; BZ: bortezomib; ER: endoplasmic reticulum; DMSO: dimethyl sulfoxide; ERAD: ER-associated protein degradation; FBS: fetal bovine serum; IRE1 $\alpha$ : inositolrequiring enzyme $1 \alpha$; MC: mast cell; MCL: mast cell leukemia; MM: multiple myeloma; PERK: doublestranded RNA-activated protein kinase-like ER kinase; PI: propidium iodide; RIDD: regulated IRE1-dependent decay of mRNA; SM: systemic mastocytosis; TKI: tyrosine kinase inhibitor; TM: tunicamycin; UPR: unfolded protein response.

\section{Authors' contributions}

TW, BKM, and MH designed and initiated the study; TW performed most of the experiments and prepared the figures; FB, KP, and VM performed experiments; TW, FB, $\mathrm{KP}, \mathrm{VM}$, and $\mathrm{MH}$ analyzed data; $\mathrm{MKC}$ and $\mathrm{BT}$ contributed new reagents; $\mathrm{MH}, \mathrm{TW}$, and $\mathrm{BT}$ wrote the manuscript; all authors read and approved the final manuscript.

\section{ACKNOWLEDGMENTS}

$\mathrm{K}$. Maschke-Neuß is acknowledged for excellent technical assistance.

\section{CONFLICTS OF INTEREST}

The authors declare that they have no conflicts of interest. 


\section{FUNDING}

This work was supported by an intramural grant by the START Program of the Medical Faculty of the RWTH Aachen University (TW, 691517).

\section{REFERENCES}

1. Balchin D, Hayer-Hartl M, Hartl FU. In vivo aspects of protein folding and quality control. Science. 2016; 353:aac4354.

2. Hetz C, Chevet E, Oakes SA. Proteostasis control by the unfolded protein response. Nat Cell Biol. 2015; 17:829-838.

3. Schroder M, Kaufman RJ. The mammalian unfolded protein response. Annu Rev Biochem. 2005; 74:739-789.

4. Mori K, Ma W, Gething MJ, Sambrook J. A transmembrane protein with a cdc2+/CDC28-related kinase activity is required for signaling from the ER to the nucleus. Cell. 1993; 74:743-756.

5. Maurel M, Chevet E, Tavernier J, Gerlo S. Getting RIDD of RNA: IRE1 in cell fate regulation. Trends Biochem Sci. 2014; 39:245-254.

6. Harding HP, Zhang Y, Bertolotti A, Zeng H, Ron D. Perk is essential for translational regulation and cell survival during the unfolded protein response. Mol Cell. 2000; 5:897-904.

7. Yoshida H, Haze K, Yanagi H, Yura $T$, Mori K. Identification of the cis-acting endoplasmic reticulum stress response element responsible for transcriptional induction of mammalian glucose-regulated proteins. Involvement of basic leucine zipper transcription factors. J Biol Chem. 1998; 273:33741-33749.

8. Obeng EA, Carlson LM, Gutman DM, Harrington WJ Jr, Lee KP, Boise LH. Proteasome inhibitors induce a terminal unfolded protein response in multiple myeloma cells. Blood. 2006; 107:4907-4916.

9. Rifkin RM, Greenspan A, Schwerkoske JF, Mandanas RA, Stephenson JJ, Kannarkat GT, Zhan F, Boehm KA, Asmar L, Beveridge R. A phase II open-label trial of bortezomib in patients with multiple myeloma who have undergone an autologous peripheral blood stem cell transplant and failed to achieve a complete response. Invest New Drugs. 2012; 30:714-722.

10. Jiang S, Zhang E, Zhang R, Li X. Altered activity patterns of transcription factors induced by endoplasmic reticulum stress. BMC Biochem. 2016; 17:8.

11. Ustun C, Arock M, Kluin-Nelemans HC, Reiter A, Sperr WR, George T, Horny HP, Hartmann K, Sotlar K, Damaj G, Hermine O, Verstovsek S, Metcalfe DD, et al. Advanced systemic mastocytosis: from molecular and genetic progress to clinical practice. Haematologica. 2016; 101:1133-1143.

12. Metcalfe DD. Mast cells and mastocytosis. Blood. 2008; 112:946-956.

13. Linnekin D. Early signaling pathways activated by c-Kit in hematopoietic cells. Int J Biochem Cell Biol. 1999;
31:1053-1074.

14. Georgin-Lavialle S, Lhermitte L, Dubreuil P, Chandesris MO, Hermine O, Damaj G. Mast cell leukemia. Blood. 2013; 121:1285-1295.

15. Soucie E, Hanssens K, Mercher T, Georgin-Lavialle S, Damaj G, Livideanu C, Chandesris MO, Acin Y, Letard S, de Sepulveda P, Hermine O, Bernard OA, Dubreuil P. In aggressive forms of mastocytosis, TET2 loss cooperates with c-KITD816V to transform mast cells. Blood. 2012; 120:4846-4849.

16. Traina F, Visconte V, Jankowska AM, Makishima H, O'Keefe CL, Elson P, Han Y, Hsieh FH, Sekeres MA, Mali RS, Kalaycio M, Lichtin AE, Advani AS, et al. Single nucleotide polymorphism array lesions, TET2, DNMT3A, ASXL1 and CBL mutations are present in systemic mastocytosis. PLoS One. 2012; 7:e43090.

17. Schwaab J, Schnittger S, Sotlar K, Walz C, Fabarius A, Pfirrmann M, Kohlmann A, Grossmann V, Meggendorfer M, Horny HP, Valent P, Jawhar M, Teichmann M, et al. Comprehensive mutational profiling in advanced systemic mastocytosis. Blood. 2013; 122:2460-2466.

18. Jawhar M, Schwaab J, Schnittger S, Sotlar K, Horny HP, Metzgeroth G, Muller N, Schneider S, Naumann N, Walz C, Haferlach T, Valent P, Hofmann WK, et al. Molecular profiling of myeloid progenitor cells in multi-mutated advanced systemic mastocytosis identifies KIT D816V as a distinct and late event. Leukemia. 2015; 29:1115-1122.

19. von Bubnoff N, Gorantla SH, Kancha RK, Lordick F, Peschel C, Duyster J. The systemic mastocytosis-specific activating cKit mutation $\mathrm{D} 816 \mathrm{~V}$ can be inhibited by the tyrosine kinase inhibitor AMN107. Leukemia. 2005; 19:1670-1671.

20. Verstovsek S, Akin C, Manshouri T, Quintas-Cardama A, Huynh L, Manley P, Tefferi A, Cortes J, Giles FJ, Kantarjian H. Effects of AMN107, a novel aminopyrimidine tyrosine kinase inhibitor, on human mast cells bearing wildtype or mutated codon 816 c-kit. Leuk Res. 2006; 30:13651370.

21. Gleixner KV, Mayerhofer M, Sonneck K, Gruze A, Samorapoompichit P, Baumgartner C, Lee FY, Aichberger KJ, Manley PW, Fabbro D, Pickl WF, Sillaber C, Valent P. Synergistic growth-inhibitory effects of two tyrosine kinase inhibitors, dasatinib and PKC412, on neoplastic mast cells expressing the D816V-mutated oncogenic variant of KIT. Haematologica. 2007; 92:1451-1459.

22. Gleixner KV, Peter B, Blatt K, Suppan V, Reiter A, Radia D, Hadzijusufovic E, Valent P. Synergistic growthinhibitory effects of ponatinib and midostaurin (PKC412) on neoplastic mast cells carrying KIT D816V. Haematologica. 2013; 98:1450-1457.

23. Gleixner KV, Mayerhofer $M$, Aichberger KJ, Derdak S, Sonneck K, Bohm A, Gruze A, Samorapoompichit P, Manley PW, Fabbro D, Pickl WF, Sillaber C, Valent P. PKC412 inhibits in vitro growth of neoplastic human mast cells expressing the D816V-mutated variant of KIT: 
comparison with AMN107, imatinib, and cladribine (2CdA) and evaluation of cooperative drug effects. Blood. 2006; 107:752-759.

24. Jin B, Ding K, Pan J. Ponatinib induces apoptosis in imatinib-resistant human mast cells by dephosphorylating mutant D816V KIT and silencing beta-catenin signaling. Mol Cancer Ther. 2014; 13:1217-1230.

25. Giansanti $\mathrm{P}$, Preisinger $\mathrm{C}$, Huber $\mathrm{KV}$, Gridling $\mathrm{M}$, Superti-Furga G, Bennett KL, Heck AJ. Evaluating the promiscuous nature of tyrosine kinase inhibitors assessed in A431 epidermoid carcinoma cells by both chemical- and phosphoproteomics. ACS Chem Biol. 2014; 9:1490-1498.

26. Kitagawa D, Yokota K, Gouda M, Narumi Y, Ohmoto H, Nishiwaki E, Akita K, Kirii Y. Activity-based kinase profiling of approved tyrosine kinase inhibitors. Genes Cells. 2013; 18:110-122.

27. Rix U, Hantschel O, Durnberger G, Remsing Rix LL, Planyavsky M, Fernbach NV, Kaupe I, Bennett KL, Valent P, Colinge J, Kocher T, Superti-Furga G. Chemical proteomic profiles of the BCR-ABL inhibitors imatinib, nilotinib, and dasatinib reveal novel kinase and nonkinase targets. Blood. 2007; 110:4055-4063.

28. Peter B, Winter GE, Blatt K, Bennett KL, Stefanzl G, Rix U, Eisenwort G, Hadzijusufovic E, Gridling M, Dutreix C, Hoermann G, Schwaab J, Radia D, et al. Target interaction profiling of midostaurin and its metabolites in neoplastic mast cells predicts distinct effects on activation and growth. Leukemia. 2016; 30:464-472.

29. Hochhaus A, Baccarani M, Giles FJ, le Coutre PD, Muller MC, Reiter A, Santanastasio H, Leung M, Novick S, Kantarjian HM. Nilotinib in patients with systemic mastocytosis: analysis of the phase 2, open-label, singlearm nilotinib registration study. J Cancer Res Clin Oncol. 2015; 141:2047-2060.

30. Gotlib J, Kluin-Nelemans HC, George TI, Akin C, Sotlar K, Hermine O, Awan FT, Hexner E, Mauro MJ, Sternberg DW, Villeneuve M, Huntsman Labed A, Stanek EJ, et al. Efficacy and Safety of Midostaurin in Advanced Systemic Mastocytosis. N Engl J Med. 2016; 374:2530-2541.

31. Peter B, Gleixner KV, Cerny-Reiterer S, Herrmann H, Winter V, Hadzijusufovic E, Ferenc V, Schuch K, Mirkina I, Horny HP, Pickl WF, Mullauer L, Willmann M, et al. Polo-like kinase-1 as a novel target in neoplastic mast cells: demonstration of growth-inhibitory effects of small interfering RNA and the Polo-like kinase-1 targeting drug BI 2536. Haematologica. 2011; 96:672-680.

32. Gleixner KV, Mayerhofer M, Cerny-Reiterer S, Hormann G, Rix U, Bennett KL, Hadzijusufovic E, Meyer RA, Pickl WF, Gotlib J, Horny HP, Reiter A, MitterbauerHohendanner G, et al. KIT-D816V-independent oncogenic signaling in neoplastic cells in systemic mastocytosis: role of Lyn and Btk activation and disruption by dasatinib and bosutinib. Blood. 2011; 118:1885-1898.

33. Papandreou I, Denko NC, Olson M, Van Melckebeke H, Lust S, Tam A, Solow-Cordero DE, Bouley DM, Offner
F, Niwa M, Koong AC. Identification of an Irelalpha endonuclease specific inhibitor with cytotoxic activity against human multiple myeloma. Blood. 2011; 117:13111314.

34. Ghosh R, Wang L, Wang ES, Perera BG, Igbaria A, Morita S, Prado K, Thamsen M, Caswell D, Macias H, Weiberth KF, Gliedt MJ, Alavi MV, et al. Allosteric inhibition of the IRE1alpha RNase preserves cell viability and function during endoplasmic reticulum stress. Cell. 2014; 158:534548.

35. Hideshima $\mathrm{T}$, Richardson $\mathrm{P}$, Chauhan $\mathrm{D}$, Palombella VJ, Elliott PJ, Adams J, Anderson KC. The proteasome inhibitor PS-341 inhibits growth, induces apoptosis, and overcomes drug resistance in human multiple myeloma cells. Cancer Res. 2001; 61:3071-3076.

36. Adams J. Proteasome inhibition in cancer: development of PS-341. Semin Oncol. 2001; 28:613-619.

37. Nawrocki ST, Carew JS, Dunner K Jr, Boise LH, Chiao PJ, Huang P, Abbruzzese JL, McConkey DJ. Bortezomib inhibits PKR-like endoplasmic reticulum (ER) kinase and induces apoptosis via ER stress in human pancreatic cancer cells. Cancer Res. 2005; 65:11510-11519.

38. Meriin AB, Gabai VL, Yaglom J, Shifrin VI, Sherman MY. Proteasome inhibitors activate stress kinases and induce Hsp72. Diverse effects on apoptosis. J Biol Chem. 1998; 273:6373-6379.

39. Yu M, Luo J, Yang W, Wang Y, Mizuki M, Kanakura Y, Besmer P, Neel BG, Gu H. The scaffolding adapter Gab2, via Shp-2, regulates kit-evoked mast cell proliferation by activating the Rac/JNK pathway. J Biol Chem. 2006; 281:28615-28626.

40. Timokhina I, Kissel H, Stella G, Besmer P. Kit signaling through PI 3-kinase and Src kinase pathways: an essential role for Rac1 and JNK activation in mast cell proliferation. EMBO J. 1998; 17:6250-6262.

41. Wagner EF, Nebreda AR. Signal integration by JNK and p38 MAPK pathways in cancer development. Nat Rev Cancer. 2009; 9:537-549.

42. Zhang T, Inesta-Vaquera F, Niepel M, Zhang J, Ficarro SB, Machleidt T, Xie T, Marto JA, Kim N, Sim T, Laughlin JD, Park H, LoGrasso PV, et al. Discovery of potent and selective covalent inhibitors of JNK. Chem Biol. 2012; 19:140-154.

43. Urano F, Wang X, Bertolotti A, Zhang Y, Chung P, Harding HP, Ron D. Coupling of stress in the ER to activation of JNK protein kinases by transmembrane protein kinase IRE1. Science. 2000; 287:664-666.

44. Zhou C, Martinez E, Di Marcantonio D, Solanki-Patel N, Aghayev T, Peri S, Ferraro F, Skorski T, Scholl C, Frohling $\mathrm{S}$, Balachandran S, Wiest DL, Sykes SM. JUN is a key transcriptional regulator of the unfolded protein response in acute myeloid leukemia. Leukemia. 2017; 31:1196-1205.

45. Yoshida H, Okada T, Haze K, Yanagi H, Yura T, Negishi M, Mori K. ATF6 activated by proteolysis binds in the 
presence of NF-Y (CBF) directly to the cis-acting element responsible for the mammalian unfolded protein response. Mol Cell Biol. 2000; 20:6755-6767.

46. Shirley CM, Chen J, Shamay M, Li H, Zahnow CA, Hayward SD, Ambinder RF. Bortezomib induction of C/ EBPbeta mediates Epstein-Barr virus lytic activation in Burkitt lymphoma. Blood. 2011; 117:6297-6303.

47. Mitsiades N, Mitsiades CS, Richardson PG, Poulaki V, Tai YT, Chauhan D, Fanourakis G, Gu X, Bailey C, Joseph M, Libermann TA, Schlossman R, Munshi NC, et al. The proteasome inhibitor PS-341 potentiates sensitivity of multiple myeloma cells to conventional chemotherapeutic agents: therapeutic applications. Blood. 2003; 101:23772380.

48. Cross BC, Bond PJ, Sadowski PG, Jha BK, Zak J, Goodman JM, Silverman RH, Neubert TA, Baxendale IR, Ron D, Harding HP. The molecular basis for selective inhibition of unconventional mRNA splicing by an IRE1-binding small molecule. Proc Natl Acad Sci U S A. 2012; 109:E869-878.

49. Mimura N, Fulciniti M, Gorgun G, Tai YT, Cirstea D, Santo L, Hu Y, Fabre C, Minami J, Ohguchi H, Kiziltepe T, Ikeda H, Kawano Y, et al. Blockade of XBP1 splicing by inhibition of IRE1alpha is a promising therapeutic option in multiple myeloma. Blood. 2012; 119:5772-5781.

50. Raedler L. Velcade (Bortezomib) Receives 2 New FDA Indications: For Retreatment of Patients with Multiple Myeloma and for First-Line Treatment of Patients with Mantle-Cell Lymphoma. Am Health Drug Benefits. 2015; 8:135-140.

51. Hideshima T, Mitsiades C, Akiyama M, Hayashi T, Chauhan D, Richardson P, Schlossman R, Podar K, Munshi NC, Mitsiades N, Anderson KC. Molecular mechanisms mediating antimyeloma activity of proteasome inhibitor PS-341. Blood. 2003; 101:1530-1534.

52. Dai Y, Rahmani M, Grant S. Proteasome inhibitors potentiate leukemic cell apoptosis induced by the cyclindependent kinase inhibitor flavopiridol through a SAPK/ JNK- and NF-kappaB-dependent process. Oncogene. 2003; 22:7108-7122.
53. Ramezani-Rad P, Geng H, Hurtz C, Chan LN, Chen Z, Jumaa H, Melnick A, Paietta E, Carroll WL, Willman CL, Lefebvre V, Muschen M. SOX4 enables oncogenic survival signals in acute lymphoblastic leukemia. Blood. 2013; 121:148-155.

54. Bogoyevitch MA, Kobe B. Uses for JNK: the many and varied substrates of the c-Jun N-terminal kinases. Microbiol Mol Biol Rev. 2006; 70:1061-1095.

55. Oppermann FS, Gnad F, Olsen JV, Hornberger R, Greff Z, Keri G, Mann M, Daub H. Large-scale proteomics analysis of the human kinome. Mol Cell Proteomics. 2009; 8:17511764.

56. Milani M, Rzymski T, Mellor HR, Pike L, Bottini A, Generali D, Harris AL. The role of ATF4 stabilization and autophagy in resistance of breast cancer cells treated with Bortezomib. Cancer Res. 2009; 69:4415-4423.

57. Butterfield JH, Weiler D, Dewald G, Gleich GJ. Establishment of an immature mast cell line from a patient with mast cell leukemia. Leuk Res. 1988; 12:345-355.

58. Liu L, Damen JE, Cutler RL, Krystal G. Multiple cytokines stimulate the binding of a common 145-kilodalton protein to Shc at the Grb2 recognition site of Shc. Mol Cell Biol. 1994; 14:6926-6935.

59. Zotz JS, Wolbing F, Lassnig C, Kauffmann M, Schulte U, Kolb A, Whitelaw B, Muller M, Biedermann T, Huber M. CD13/aminopeptidase $\mathrm{N}$ is a negative regulator of mast cell activation. FASEB J. 2016; 30:2225-2235.

60. Pfaffl MW. A new mathematical model for relative quantification in real-time RT-PCR. Nucleic Acids Res. 2001; 29:e45. 